\title{
A execução das decisões emanadas da Corte interamericana de direitos humanos e do sistema jurídico brasileiro e seus efeitos
}

\author{
Juliana Corbacho Neves dos Santos
}

\section{Resumo}

Em caso de conflito material entre o conteúdo de uma decisão emanada da Corte Interamericana de Direitos Humanos e o de uma decisão prolatada pelo Supremo Tribunal Federal, que versem sobre o mesmo objeto, qual deles produzirá efeitos no Direito brasileiro? A Lei $n^{\circ} 6.683$, de 1979, ou Lei da Anistia, foi examinada pela instância internacional e pelo Supremo Tribunal e, como se evidenciou, as decisões divergiram sobre a sua aplicação, notadamente quanto à punição dos agentes que praticaram as violações de direitos humanos. Qual dessas decisões será levada a produzir efeitos no plano interno, em detrimento da outra? Pretendo verificar as relações travadas entre as instâncias internacional e interna e propor caminhos para responder a algumas questões postas e aferir se o sistema jurídico brasileiro está apto a receber uma decisão internacional desafiadora e que solução seria possível ou provável. Assim, a hipótese deste estudo centra-se na necessidade de norma que regule as relações existentes entre as duas instâncias. Para tanto, serão utilizadas algumas ferramentas da teoria dos sistemas e serão analisadas normas de outros países que tratam do tema. Afinal, como poderia ser descrita a relação entre Sistema Interamericano de Proteção de Direitos Humanos e ordenamento jurídico brasileiro? Integração, interação ou antinomia?

Palavras-chave: Direito Internacional. Corte Interamericana de Direitos Humanos. Direitos humanos. Justiça internacional.

1 Graduada em Direito pela Universidade Federal da Bahia e mestranda em Direito pelo Centro Universitário de Brasília, linha de pesquisa proteção internacional à pessoa humana. É advogada da União desde 2003, lotada na Secretaria de Direitos Humanos da Presidência da República, onde atua na Assessoria Internacional. 


\section{Apresentação do tema}

Em caso de conflito material entre o conteúdo de uma decisão emanada da Corte Interamericana de Direitos Humanos e o de uma decisão prolatada pelo Supremo Tribunal Federal, que versem sobre o mesmo objeto, qual deles produzirá efeitos no Direito brasileiro? A resposta a essa questão não é tão simples quanto pode parecer à primeira vista. Se o objeto dessas decisões for uma questão sobre a qual o país estava debatendo, em meio a muitas posições conflitantes, e ainda não havia chegado a um entendimento compartilhado por uma boa parte das pessoas, das instituições e dos órgãos públicos, como esses dois órgãos, um internacional, outro nacional, lidariam com a controvérsia entre eles? Parece que a situação pode se complicar ainda mais, dependendo do objeto do conflito.

Em 26 de março de 2009, a Comissão Interamericana de Direitos Humanos submeteu à apreciação da Corte Interamericana de Direitos Humanos o Caso "Julia Gomes Lund e Outros" (Guerrilha do Araguaia), que estava sob sua análise desde 7 de agosto de 1995. Conforme alegado pelos peticionários, a denúncia versou sobre a detenção ilegal e arbitrária, tortura e desaparecimento forçado de pelo menos 70 membros do movimento conhecido como Guerrilha do Araguaia entre os anos de 1972 e 1975 e da consequente falta de investigação desses atos, o que se relaciona com a edição da Lei ${ }^{\circ}$ 6.683, de 28 de agosto de 1979, Lei da Anistia, e com o sigilo permanente sobre documentos a respeito dessa operação estatal. Em 2008, a Comissão Interamericana emitiu o relatório de mérito do Caso, no qual formulou recomendações ao Estado brasileiro. Por entender que as suas recomendações não haviam sido cumpridas a contento, posteriormente, decidiu encaminhar o Caso à Corte Interamericana de Direitos Humanos.

A Corte Interamericana de Direitos Humanos realizou audiência nos dias 20 e 21 de maio passado, na qual foram ouvidos os representantes das vítimas, suas testemunhas e peritos, os representantes da Comissão Interamericana de Direitos Humanos e os representantes do Estado brasileiro e, igualmente, suas testemunhas e peritos. Cada parte apresentou suas razões e a Corte Interamericana passou à elaboração da sentença. 
Em 14 de dezembro de 2010, foi divulgada pela Corte a decisão prolatada no Caso em exame, datada de 24 de novembro de 2010. Quanto às questões preliminares invocadas pelo Estado, a Corte Interamericana reconheceu parcialmente apenas uma delas, para declarar a sua competência a partir da data em que o Brasil reconheceu a competência contenciosa da Corte, ou seja, a partir de 10 de dezembro de 1998. Com isso, o exame de mérito sobre os fatos referiu-se àqueles ocorridos após essa data.

O Brasil foi condenado nessa decisão pelo desaparecimento forçado das pessoas que participaram da Guerrilha do Araguaia e, portanto, pela violação aos direitos ao reconhecimento da personalidade jurídica (artigo 3), à vida (artigo 4), à integridade pessoal (artigo 5) e à liberdade pessoal (artigo 7), bem como pela violação aos direitos às garantias judiciais (artigo 8) e à proteção judicial (artigo 25), em razão da interpretação que foi dada à Lei da Anistia, que impediu a investigação dos fatos e a punição dos responsáveis pelas condutas indicadas, e da demora na tramitação da Ação Ordinária nº 82.0024682-5.

Em razão das violações das disposições da Convenção Americana sobre Direitos Humanos apontadas, a Corte determinou que o Estado deve adotar medidas para determinar o paradeiro das vítimas desaparecidas e, se for o caso, identificar os seus restos mortais e oferecer tratamento psicológico ou psiquiátrico às vítimas, mediante requerimento, custeado pelo Estado. Foi determinada também a publicação da íntegra da decisão no Diário Oficial e em um sítio eletrônico do Estado, devendo ficar disponível na internet pelo período de um ano. A decisão deve ser disponibilizada, em formato de um livro eletrônico, também em um sítio do Estado. O resumo oficial da sentença proferida pela Corte deve ser publicado em um jornal de ampla circulação nacional. Essas providências de divulgação da sentença devem ser adotadas no prazo de seis meses, contados da data de notificação do Estado.

Segundo a decisão, o Estado deve realizar um ato público de reconhecimento da responsabilidade internacional pelas violações indicadas no Caso, uma cerimônia pública, com a presença de altas autoridades nacionais e das vítimas do Caso, devendo o Estado acordar com elas as circunstâncias da cerimônia, que 
deve ser divulgada amplamente em meios de comunicação. Foi prevista a realização de ações de capacitação e de um programa ou curso permanente e obrigatório sobre direitos humanos, voltados ao pessoal integrante de todos os níveis hierárquicos das Forças Armadas, que deve incluir a sentença do Caso, a jurisprudência da Corte Interamericana sobre desaparecimento forçado de pessoas, outras graves violações aos direitos humanos e sobre a jurisdição penal militar, bem como as obrigações internacionais de direitos humanos assumidas pelo Brasil em tratados dos quais ele é parte.

Foi determinado, ainda, que continuem as iniciativas de busca, sistematização e publicação de informação sobre a Guerrilha do Araguaia e sobre as violações de direitos humanos ocorridas durante o regime militar. Em razão das violações reconhecidas na sentença, a Corte determinou ao Estado o pagamento de indenizações por danos materiais, imateriais e por restituição de custas e gastos às vítimas indicadas.

O Estado deve, ainda, adotar, em um prazo razoável, providências para tipificar o crime de desaparecimento forçado de pessoas, em conformidade com os parâmetros fixados pela sentença. Enquanto isso não for cumprido, ele deve adotar medidas para o julgamento e a punição dos responsáveis pelos fatos, utilizando os mecanismos já existentes no Direito brasileiro. Sobre esse tema, a sentença esclareceu que a interpretação e a aplicação da Lei da Anistia impediram a efetiva promoção das ações que se faziam necessárias e afirmou a obrigação do Estado em conduzir eficazmente a investigação, a apuração penal dos fatos perante as instâncias internas e a aplicação das sanções e consequências previstas em lei.

Os órgãos do Estado brasileiro foram notificados da decisão do Caso Gomes Lund e Outros no mês de dezembro de 2010 e ainda não há notícia, até o momento, do cumprimento dos pontos resolutivos acima apontados.

Paralelo a isso, a Ordem dos Advogados do Brasil (OAB), em 21 de outubro de 2008, ingressou com a Arguição de Descumprimento de Preceito Fundamental (ADPF) $n^{\circ} 153$ perante o Supremo Tribunal Federal (STF), em razão de, segundo a inicial, haver notória controvérsia constitucional quanto ao artigo $1^{\circ}$ da Lei $\mathrm{n}^{\circ}$ 6.683, de 28 de agosto de 1979, anterior à Constituição Federal de 1988. 
$\mathrm{Na}$ ADPF, foi formulado o seguinte pedido:

b) a procedência do pedido de mérito, para que esse Colendo Tribunal dê à Lei $\mathrm{n}^{\circ} 6.683$, de 28 de agosto de 1979, interpretação conforme a Constituição, de modo a declarar, à luz de seus preceitos fundamentais, que a anistia concedida pela citada lei aos crimes políticos ou conexos não se estende aos crimes comuns praticados pelos agentes da repressão contra opositores políticos, durante o regime militar $(1964 / 1985) .^{2}$

O Supremo Tribunal Federal, na sessão ocorrida alguns dias antes da audiência da Corte Interamericana acima mencionada, iniciada em 28 e concluída em 29 de abril, julgou a ADPF n ${ }^{\circ} 153$ por seu Pleno e, por maioria de sete votos a dois, decidiu pela improcedência da Arguição segundo o voto do Ministro relator, por entender que a Lei de Anistia concedeu o esquecimento a todos os crimes praticados no período do regime militar autoritário, em uma interpretação ampla e distinta do que pleiteava a $\mathrm{OAB}$.

Após a promulgação da Constituição Federal em outubro de 1988, a democracia no Brasil vem se consolidando com fundamento na cidadania e a dignidade da pessoa humana, colocando os direitos fundamentais em um lugar de especial destaque no Estado Democrático de Direito. ${ }^{3}$ Nesse contexto, aos tratados de direitos humanos receberam disciplina inédita no texto constitucional, que os consagrou como fonte de direitos fundamentais não previstos no seu texto original, tal como inscrito no seu artigo $5^{\circ}$, parágrafo $2^{\circ}$. Ainda, por força da Emenda Constitucional $n^{\circ} 45$, de 8 de dezembro de 2004, a Constituição passou a determinar que os tratados de direitos humanos que forem aprovados, em cada Casa do Congresso Nacional, em dois turnos, por três quintos dos votos dos respectivos membros, serão equivalentes às emendas constitucionais. O Brasil ratificou e promoveu a recepção em seu ordenamento de diversos tratados sobre a matéria, em especial, a

2 Petição inicial consultada no sítio do Supremo Tribunal Federal na internet. Disponível em: <www.stf.jus.br>. Acesso em: 22 jan. 2010.

3 PIOVESAN, Flávia. Direitos humanos e o direito constitucional internacional. São Paulo: Saraiva, 2007. p. 21 et. seq. 
Convenção Americana sobre Direitos $\operatorname{Humanos}^{4}$ e, posteriormente, submeteu-se à jurisdição ${ }^{5}$ da Corte Interamericana, o que demonstra a inserção do país no cenário internacional de proteção, garantia e promoção dos direitos fundamentais.

No presente momento, a combinação dos fatos acima descritos coloca um desafio ao Estado brasileiro. O questionamento sobre a extensão e a própria legitimidade (aqui entendida em um sentido mais amplo, de conformidade com as normas internacionais na primeira situação e com as normas constitucionais na segunda) da Lei $n^{\circ}$ 6.683, de 1979, ou Lei da Anistia, foi submetido a uma instância internacional e a mais alta instância nacional simultaneamente. Ambas já prolataram o seu entendimento sobre a matéria, pondo um fim às controvérsias que se apresentavam, e o desafio ao Estado reside exatamente na execução dos pontos resolutivos da decisão internacional, em face do conteúdo conflitante das duas decisões.

Os efeitos da decisão da Corte Interamericana no Caso mencionado potencialmente podem ser inéditos na experiência brasileira. Até a prolação da sentença do Caso "Gomes Lund e Outros", desde a aceitação da jurisdição da Corte Interamericana de Direitos Humanos, o Brasil havia sido condenado em três Casos: Ximenes Lopes, Escher e Outros, e Garibaldi. Em nenhum deles, vale frisar, o sistema jurídico brasileiro foi tão posto à prova como no Caso mencionado, pois um dos pedidos referiu-se precisamente à revogação da Lei de Anistia, objeto de uma intensa discussão entre instituições e atores estatais e sociais, sem a sedimentação de um entendimento preponderante na sociedade brasileira.

Nos três casos anteriores, a condenação do Estado brasileiro cingiu-se, em regra, ao pagamento de indenizações, à investigação dos fatos, à punição daqueles que a eles deram causa, à publicação da sentença e à realização de políticas públicas voltadas a prevenir violações de direitos humanos semelhantes no país. Não houve

4 BRASIL. Decreto $n^{\circ}$ 678, de 1992. Disponível em: <www.presidencia.gov.br>. Acesso em: 14 jan. 2010.

5 Decreto ${ }^{\circ} 89$, de 1998, que reconheceu a competência obrigatória da Corte Interamericana de Direitos Humanos em todos os casos relativos à interpretação ou aplicação da Convenção Americana de Direitos Humanos. 
condenação do Estado brasileiro a revogar ou anular alguma norma interna ou, ainda, a adotar medidas fortemente contrárias a normas internas, desafiando alguns órgãos e instituições do Estado, diferente do que já ocorreu em casos relativos a outros países submetidos à Corte Interamericana de Direitos Humanos.

Um dos precedentes mais conhecidos entre os casos que tramitaram na Corte é o "A Última Tentação de Cristo", Olmedo Bustos contra Chile, cuja sentença foi prolatada em 5 de fevereiro de 2001, que dizia respeito à censura estatal prévia ao filme que deu nome ao Caso. A censura prévia à exibição de obras artísticas e, portanto, a limitação absoluta à liberdade de expressão tinha amparo em norma constitucional chilena, que, no entendimento da Corte, violou a Convenção Americana sobre Direitos Humanos. O Estado chileno foi condenado a modificar o seu ordenamento jurídico interno de modo a suprimir a norma que autorizava a censura prévia, o que significou, nesse Caso, uma alteração de norma constitucional. Afastando-se aqui a discussão sobre a estatura interna dos tratados que versam sobre direitos humanos, que não nos interessa por hora, é importante perceber que a Corte produziu contundente interferência no direito interno chileno, mais precisamente na sua constituição, ficando evidente como podem ser significativos os efeitos das decisões internacionais no campo dos direitos humanos.

Assim, o Caso "Julia Gomes Lund e Outros" (Guerrilha do Araguaia) certamente trouxe e ainda traz desafios ao Estado brasileiro. O primeiro deles foi apresentar à instância internacional uma manifestação sobre o seu entendimento a respeito do tema da anistia, o que estava em acalorado debate na sociedade brasileira: as informações prestadas ${ }^{6}$ pela Advocacia-Geral da União (AGU) na ADPF $n^{\circ} 153$ consistiram nas considerações feitas pela própria AGU e nas informações prestadas pela Secretaria Especial dos Direitos Humanos e pela Casa Civil, ambas da Presidência da República, pelo Ministério das Relações Exteriores, pelo Ministério da Justiça e pelo Ministério da Defesa, com posições divergentes entre si. Na audiência ocorrida em 20 e 21 de maio de 2010, o Estado brasileiro levou

6 Peça relativa às informações prestadas pela Advocacia-Geral da União na ADPF n ${ }^{\circ} 153$ constante do sítio do Supremo Tribunal Federal. Disponível em: <www.stf.jus.br >. Acesso em: 30 jan. 2010. 
representantes desses órgãos e expressou perante a Corte Interamericana razões que contemplavam principalmente a recente decisão do Supremo Tribunal Federal na $A D P F n^{\circ} 153$, somada a alguns elementos defendidos por cada um deles. $O$ segundo desafio será a execução da sentença expedida pela Corte, que expressa entendimento e conclusão diversos daqueles expostos pelo STF na ADPF n ${ }^{\circ} 153$. Assim, surgem as questões que interessam a este trabalho. Será dado integral cumprimento à decisão da instância internacional? Como os sistemas internacional e interno se relacionam? O sistema jurídico brasileiro está preparado para receber uma decisão internacional que lhe imponha uma mudança significativa?

Diante disso, pretendemos verificar as relações travadas entre a instância internacional e a instância interna brasileira e a necessidade de uma legislação para disciplinar essas relações. Se confirmada a hipótese da necessidade de regramento específico para o tema, será verificada a possibilidade de propor caminhos para responder às questões já postas, em outras palavras, será analisada de que forma essas instâncias interagem entre si, se elas formam um só sistema ou sistemas distintos e, se distintos, como esses sistemas se relacionam. O objetivo deste trabalho é aferir se o sistema jurídico brasileiro está apto a receber uma decisão internacional desafiadora e que solução seria possível ou provável em caso de conflito material entre o conteúdo de uma decisão da Corte Interamericana de Direitos Humanos e o de uma do Supremo Tribunal Federal. Afinal, como poderia ser descrita a relação entre Sistema Interamericano de Proteção de Direitos Humanos e ordenamento jurídico brasileiro? Integração, interação ou antinomia?

\section{Noções preliminares sobre a análise de diferentes sistemas}

É importante analisar se o ordenamento jurídico brasileiro e o Sistema Interamericano de Proteção de Direitos Humanos, criado pela Convenção Americana sobre Direitos Humanos, formam apenas um sistema ou dois sistemas distintos. Na primeira hipótese, deve ser verificado como as duas instâncias do mesmo sistema se comunicam. Na segunda hipótese, devem ser investigadas as relações entre os dois sistemas, quais as suas formas de interação e como um conflito pode ser dirimido entre eles. Para tanto, vamos utilizar algumas ferramentas da teoria dos 
sistemas. ${ }^{7}$ As respostas a essas questões são fundamentais para a compreensão de algumas dificuldades enfrentadas no cumprimento das decisões da Corte Interamericana de Direitos Humanos.

Um sistema é formado quando ele é capaz de reduzir a sua complexidade e diferenciar-se do seu entorno, ${ }^{8}$ criando uma identidade própria. Uma característica do sistema é a sua diferenciação temporal em relação ao entorno, ${ }^{9}$ uma vez que o que acontece no ambiente não sucede ao mesmo tempo no sistema. Essa característica é bastante perceptível nos sistemas jurídicos em geral: há muitas demandas que ainda não são recebidas e disciplinadas pelo direito, mas que já se encontram assentadas na sociedade, enquanto, outras vezes, é a norma que serve de indutor de condutas para a sociedade. O descompasso entre os momentos em que os fatos ocorrem dentro e fora do sistema jurídico decorre da regulação a que o sistema deve obedecer, da sua linguagem própria e da sua forma particular de receber e processar os fatos do entorno. Porém, o sistema sempre existe simultaneamente ao seu entorno ${ }^{10}$. Em poucas palavras, o sistema é um "[...] conjunto de elementos que interagem entre si e que, ao fazê-lo, se diferenciam mediante limites de um entorno com o qual se comunicam". ${ }^{11}$

Os limites impostos pelo sistema garantem que ele não se confunda com o seu entorno e mantenha a diferenciação em relação a ele. A previsão de limites não impede que o sistema se relacione com o seu entorno, nele presentes outros sistemas, mas permite que o sistema selecione as relações que estabelecerá com o entorno. Sem esse mecanismo de limitação, o sistema desaparece, por se confundir com o seu entorno.

7 É importante esclarecer que, neste trabalho, foram utilizados apenas alguns conceitos relativos à teoria dos sistemas propostos por Niklas Luhmann, não a sua teoria na integralidade.

8 SERRANO, José Luís. La diferencia riesgo/peligro. In: VARELLA, Marcelo Dias (Org.). Direito, sociedade e riscos. Brasília: UniCEUB; UNITAR, 2006. p. 71.

9 SERRANO, José Luís. La diferencia riesgo/peligro. In: VARELLA, Marcelo Dias (Org.). Direito, sociedade e riscos. Brasília: UniCEUB; UNITAR, 2006. p. 72.

${ }^{10}$ LUHMANN, Niklas. Risk: a sociological theory. Traduzido por Rhodes Barret. New York: Aldine de Gruyter, 1993. p. 35.

${ }^{11}$ SERRANO, José Luís. La diferencia riesgo/peligro. In: VARELLA, Marcelo Dias (Org.). Direito, sociedade e riscos. Brasília: UniCEUB; UNITAR, 2006. p. 79. 
A comunicação do sistema com o seu entorno, no qual pode haver outros sistemas distintos dele, é uma operação autopoiética entre eles, ${ }^{12}$ uma "[...] síntese de informação, transmissão e compreensão que reproduz o sistema em cada momento". ${ }^{13} \mathrm{O}$ sistema, assim, assimila os fatos do entorno de acordo com as suas próprias regras nas suas operações comunicativas, uma vez que ele, fundado em seus códigos, entenderá o fato como justo/injusto, racional/irracional, legítimo/ ilegítimo segundo a sua racionalidade própria.

Em suma, para se caracterizar um conjunto de elementos (instituições, normas, princípios) como um sistema, é necessário que seja analisado se ele se diferencia do seu entorno, se possui complexidade reduzida em relação a ele, se tem normas próprias e distintas daquelas do entorno, se possui um código próprio e se estabelece limites e relações de comunicação com o entorno e outros sistemas.

\section{0 sistema interamericano de proteção de direitos humanos e o direito brasileiro: um ou dois sistemas}

Com a adesão do Estado brasileiro ao Sistema Regional Interamericano de Proteção dos Direitos Humanos em 1992 e, especialmente, com a submissão à jurisdição da Corte Interamericana de Direitos Humanos, o Brasil comprometeu-se internacionalmente a promover e a proteger os direitos humanos elencados na Convenção Americana sobre Direitos Humanos - Pacto de San José da Costa Rica - e em outros instrumentos que compõem o Sistema Interamericano. Essa Convenção, além de uma lista de direitos, previu órgãos de monitoramento e de julgamento dos Estados que a ela adiram, quanto ao cumprimento das obrigações assumidas internacionalmente.

A Comissão Interamericana de Direitos Humanos já era prevista no artigo 106 da Carta da Organização dos Estados Americanos (OEA) de 1948, porém ela

\footnotetext{
${ }^{12}$ SERRANO, José Luís. La diferencia riesgo/peligro. In: VARELLA, Marcelo Dias (Org.). Direito, sociedade e riscos. Brasília: UniCEUB; UNITAR, 2006. p. 82.

${ }^{13}$ LUHMANN, Niklas. Risk: a sociological theory. Traduzido por Rhodes Barret. New York: Aldine de Gruyter, 1993. p. 162.
} 
ganhou novas feições e funções na Convenção Americana sobre Direitos Humanos. A Comissão tem a função principal de promover a observância e a defesa dos direitos humanos, atuando no monitoramento dos Estados no tocante ao cumprimento dos compromissos por eles assumidos no âmbito da OEA e funcionando como uma instância prévia ao envio de casos à Corte Interamericana de Direitos Humanos. Após o trâmite da demanda na Comissão, ela decide se adota medidas próprias ou se encaminha o caso à Corte Interamericana de Direitos Humanos, dando início à tramitação de um processo judicial sobre o assunto. Nos termos do artigo 61 da Convenção Americana sobre Direitos Humanos, somente os Estados e a Comissão podem apresentar e submeter um caso à jurisdição da Corte Interamericana de Direitos Humanos. A Corte tem competência para conhecer de questão sobre a interpretação e a aplicação das disposições da Convenção Americana.

Sendo assim, a Comissão e a Corte integram o Sistema Interamericano de Proteção de Direitos Humanos, que possui, como principais normas, a Carta da OEA e a Convenção Americana sobre Direitos Humanos. Existem outras normas integrantes do Sistema Interamericano, como os protocolos adicionais à Convenção Americana sobre Direitos Humanos, Protocolo de San Salvador e Protocolo Referente à Abolição da Pena de Morte, além dos regulamentos e estatutos da Comissão e Corte Interamericanas, da Declaração Americana dos Direitos e Deveres do Homem, da Convenção Interamericana para Prevenir e Punir a Tortura, da Convenção Interamericana para a Eliminação de Todas as Formas de Discriminação contra as Pessoas Portadoras de Deficiência, da "Convenção de Belém do Pará" (Convenção Interamericana para Prevenir, Punir e Erradicar a Violência contra a Mulher) e da Convenção Interamericana sobre o Desaparecimento Forçado de Pessoas.

Essas normas preveem direitos e obrigações para os sujeitos de direito, sanções para a violação das suas regras, formas de acesso a seus órgãos, regras processuais para a tramitação dos casos, para a investidura de suas autoridades, para a execução de suas decisões, enfim, o regramento do Sistema Interamericano define a sua estrutura e a dinâmica com a qual travará as relações com o seu ambiente, sendo, com isso, possível identificá-lo como sistema, nos termos propostos pela teoria dos sistemas. 
O Sistema Interamericano tem complexidade menor que a do seu entorno, pois delimita quais as matérias passíveis de apreciação por seus órgãos e quais as formas de acesso a essas instâncias em seus instrumentos normativos e desenvolve uma racionalidade, isto é, uma lógica e uma jurisprudência próprias para o exame das violações a suas normas. Não interessam, por exemplo e em regra, os aspectos puramente econômicos dos fatos submetidos ao exame dos órgãos do Sistema Interamericano de Proteção de Direitos Humanos, nem serão analisados acordos comerciais no seu âmbito, a menos que isso tenha reflexos na proteção e promoção dos direitos humanos na América. Os órgãos integrantes do Sistema Interamericano já produziram uma jurisprudência ${ }^{14}$ sobre determinados assuntos que espelha a lógica da racionalidade do Sistema, diferente de outros órgãos internacionais e dos órgãos dos países que a ele estão sujeitos.

Ademais, os órgãos estão limitados ao exame dos fatos sob a ótica das normas integrantes do Sistema Interamericano, ainda que possam, em suas decisões, mencionar tratados que compõem o escopo normativo de outros sistemas. ${ }^{15}$ Os órgãos podem interpretar ou integrar as normas do Sistema Interamericano, considerando as particularidades dos fatos examinados, porém, sem realizar a sua aplicação direta a esses fatos para decidir sobre as violações de direitos e deveres previstos no seu escopo normativo. A aplicação direta aos fatos julgados é reservada aos textos normativos integrantes do Sistema, com base nos quais os órgãos fazem a apreciação jurídica e o julgamento dos fatos denunciados a eles.

\footnotetext{
${ }^{14}$ Um exemplo dessa afirmação são as decisões da Corte Interamericana de Direitos Humanos que envolvem o direito de povos indígenas a terras tradicionalmente ocupadas. CORTE INTERAMERICANA DE DIREITOS HUMANOS. Comunidade Mayagna (Sumo) Awas Tingni contra a Nicarágua (Sentença de 31 de agosto de 2001). CORTE INTERAMERICANA DE DIREITOS HUMANOS. Comunidade Indígena Yakye Axa contra Paraguai (Sentença de 17 de junho de 2005). CORTE INTERAMERICANA DE DIREITOS HUMANOS. Comunidade Indígena Sawhoyamaxa contra Paraguai (Sentença de 29 de março de 2006).

${ }^{15}$ CORTE INTERAMERICANA DE DIREITOS HUMANOS. Masacre Plan de Sanchez contra Guatemala (Voto do Juiz Sergio García Ramírez na sentença de 29 de abril de 2004, par. 17-20). CORTE INTERAMERICANA DE DIREITOS HUMANOS. Villagrán Morales y otros contra Guatemala ("Niños De La Calle") (Sentença de 19 de novembro de 1999, par. 192-195). CORTE INTERAMERICANA DE DIREITOS HUMANOS. Bámaca Velásquez contra Guatemala (Sentença de 25 de novembro de 2000, par. 208-210).
} 
Quanto ao ordenamento jurídico brasileiro, percebe-se que ele é dotado de regras e princípios próprios, sendo a Constituição Federal de 1988 a sua mais graduada fonte, pois ela elenca, senão todos, certamente os mais relevantes princípios e normas do sistema, que devem informar a sua racionalidade. $\mathrm{O}$ sistema jurídico interno brasileiro elege, por suas regras, que relações ele trava com o seu entorno, o que lhe interessa e o que lhe é externo. Para que uma norma ou uma decisão produza efeitos jurídicos no Brasil, o sistema determina precisamente que conteúdo ela pode ter e que procedimento ela deve observar para "ingressar" no sistema. Do contrário, essa norma ou decisão permanecerá no entorno do sistema brasileiro, ou seja, não será conhecida pelos sujeitos e pelas instituições (elementos) que o compõem.

O sistema jurídico brasileiro tem limites e prevê suas formas de comunicação com o entorno. No tema dos tratados que versam sobre direitos humanos, o ingresso desses instrumentos no ordenamento brasileiro não se dá de forma automática, pois eles devem cumprir certas regras e, segundo elas, ocuparão diferentes posições no sistema. Depois de negociados e assinados os tratados, há dois ritos previstos para o seu ingresso no Direito brasileiro. Até o ano de 2004, os tratados de direitos humanos seguiam o mesmo procedimento parlamentar de aprovação dos tratados em geral, igual ao prescrito pela Constituição Federal para a aprovação de lei ordinária. Com a aprovação da Emenda ${ }^{\circ} 45$, de 2004, que acrescentou o $\$ 3^{\circ}$ ao art. $5^{\circ}$ ao texto constitucional, foi previsto outro rito possível para a aprovação dos tratados: aqueles que, diferentemente do procedimento de aprovação previsto para as leis ordinárias, forem aprovados em cada casa legislativa, em dois turnos, por três quintos dos votos dos respectivos membros, são equivalentes às emendas constitucionais. ${ }^{16}$ Somente a partir da aprovação e publicação do texto do tratado, ele se torna integrante do sistema jurídico brasileiro, produzindo efeitos internos. Os tratados aprovados de uma ou de outra forma podem ter consequências jurídicas diferentes na sua aplicação interna, o que demonstra a importância da forma de recepção ou de comunicação do sistema brasileiro com o seu entorno nesse particular.

\footnotetext{
${ }^{16}$ A Convenção sobre os Direitos das Pessoas com Deficiência foi aprovada pelo rito previsto para as emendas constitucionais, de acordo com o $\$ 3^{\circ}$ do artigo $5^{\circ}$ da Constituição Federal de 1988. O texto foi promulgado pelo Presidente da República por meio do Decreto $\mathrm{n}^{\circ}$ 6.949, de 25 de agosto de 2009. BRASIL. Decreto $n^{\circ}$ 6.949, de 25 de agosto de 2009. Disponível em: <www.presidencia.gov.br>. Acesso em: 31 jan. 2010.
} 
A questão sobre se o Sistema Interamericano de Proteção de Direitos Humanos e o ordenamento jurídico brasileiro formam um só sistema ou dois sistemas, à luz de algumas ferramentas da teoria dos sistemas apresentadas, deve ser enfrentada, para que seja possível prever e lidar satisfatoriamente com os problemas resultantes das relações entre eles, sejam elas intrassistêmicas ou interssistêmicas. Tendo em conta os critérios da diferenciação, da existência de normas e de racionalidade próprias e da previsão de limites, parece mais adequado compreender a existência de dois sistemas distintos. Os sistemas ora examinados, pelo já exposto, parecem ser distintos, pois têm normas, limites, linguagem e racionalidades que não se confundem.

Caso se tratasse de um único sistema, os dois conjuntos comparados deveriam compartilhar os mesmos limites do entorno, a mesma racionalidade, as mesmas normas, o que não ficou evidente no exame à luz das ferramentas utilizadas aqui. A comunicação entre eles não é feita de forma automática e, de fato, ela encontra alguns obstáculos nos casos concretos. Um dos obstáculos que dizem respeito à racionalidade dos sistemas em tela é o federalismo, noção bastante prestigiada pela legislação interna, pelos tribunais e, por conseguinte, pelas instituições públicas nacionais. O Estado brasileiro está fundado em uma rígida divisão de competências entre os entes federados, o que impede que um possa realizar atividades em matéria que está contida no âmbito de atuação do outro.

Essa forma de racionalidade é muitas vezes utilizada pelos Estados como argumento para eximir-se de adotar providências e de responsabilizar-se pelas decisões que provêm dos órgãos do Sistema Interamericano de Proteção de Direitos Humanos, uma vez que, segundo essa lógica, a União representa a República Federativa do Brasil no âmbito internacional, por força da disposição contida no artigo 21, incisos I e II da Constituição Federal. Atualmente, a União, por seus órgãos competentes, ${ }^{17}$ busca o diálogo e a atuação conjunta com os Estados do Ceará e do Paraná, por exemplo, visando o cumprimento das sentenças dos Casos “Da-

\footnotetext{
${ }^{17}$ Atuam em coordenação a Secretaria de Direitos Humanos da Presidência da República, a Advocacia-Geral da União e o Ministério das Relações Exteriores no cumprimento das sentenças da Corte Interamericana de Direitos Humanos, além dos órgãos com competências específicas para cada providência.
} 
mião Ximenes Lopes", "Escher e Outros" (Interceptações Telefônicas) e "Sétimo Garibaldi”, respectivamente, porém a tarefa não é fácil. A decisão do Caso Damião Ximenes Lopes foi prolatada em julho de 2006, o Caso tramita no Sistema Interamericano desde novembro de 1999 e até hoje alguns pontos da condenação estão pendentes de cumprimento. ${ }^{18}$

Essa lógica que reafirma o federalismo e as limitações dele decorrentes não encontra ressonância no Sistema Interamericano, nas suas normas, nem nas decisões de seus órgãos. O artigo $28^{19}$ da Convenção Americana sobre Direitos Humanos dispõe sobre a cláusula federal, segundo a qual o Estado não pode alegar sua estrutura federal para justificar o descumprimento de uma obrigação internacional, devendo os compromissos serem respeitados independentemente da forma unitária ou federal do Estado. ${ }^{20}$ A complexidade da estrutura federativa brasileira, as dificuldades orçamentárias de alguns entes federados, a troca dos governantes, as dificuldades de interlocução entre Estados governados por partidos políticos

${ }^{18}$ Segundo a última resolução prolatada pela Corte Interamericana, estão pendentes de cumprimento pelo Estado brasileiro dos pontos resolutivos sexto e oitavo da sentença. CORTE INTERAMERICANA DE DIREITOS HUMANOS. Caso Ximenes Lopes contra Brasil (Resolução de 17 de maio de 2010).

${ }^{19}$ Artigo 28. Cláusula federal

1. Quando se tratar de um Estado Parte constituído como Estado federal, o governo nacional do aludido Estado Parte cumprirá todas as disposições da presente Convenção, relacionadas com as matérias sobre as quais exerce competência legislativa e judicial.

2. No tocante às disposições relativas às matérias que correspondem à competência das entidades componentes da federação, o governo nacional deve tomar imediatamente as medidas pertinentes, em conformidade com sua constituição e suas leis, a fim de que as autoridades competentes das referidas entidades possam adotar as disposições cabíveis para o cumprimento desta Convenção.

3. Quando dois ou mais Estados Partes decidirem constituir entre eles uma federação ou outro tipo de associação, diligenciarão no sentido de que o pacto comunitário respectivo contenha as disposições necessárias para que continuem sendo efetivas no novo Estado assim organizado as normas da presente Convenção.

${ }^{20}$ CORTE INTERAMERICANA DE DIREITOS HUMANOS. Garrido e Baigorria contra Argentina (Sentença de 27 de agosto de 1998, par. 46). CORTE INTERAMERICANA DE DIREITOS HUMANOS. Opinião Consultiva OC-16/99, de $1^{\circ}$ de outubro de 1999. CORTE INTERAMERICANA DE DIREITOS HUMANOS. Caso Escher e Outros contra Brasil (Sentença de 6 de julho de 2009, par. 219). CORTE INTERAMERICANA DE DIREITOS HUMANOS. Medidas Provisórias decretadas para o Presídio Urso Branco (Resolução de 2 de maio de 2008, Considerando 14). 
diferentes: nenhum desses argumentos, que têm alguma razão e, por isso, podem ser aceitos em algumas situações conforme a lógica do ordenamento jurídico brasileiro, é considerado como uma justificativa razoável para o inadimplemento de obrigação assumida no âmbito do Sistema Interamericano.

A ideia a respeito da razoável duração do processo também pode ser exemplo da diferença de lógica, de racionalidade entre as instâncias internas brasileiras e a Corte Interamericana de Direitos Humanos, como fica evidente no Caso Ximenes Lopes contra Brasil. A Corte, na decisão, ${ }^{21}$ manifestou-se expressamente sobre esse tema, afirmando que a excessiva duração do processo penal não foi razoável, tendo em vista as circunstâncias do Caso, e teve causa na conduta das autoridades por ele responsáveis. Depois da sentença, em procedimento que visou à apuração de eventual excesso de prazo no processo penal, a Corregedoria do Tribunal de Justiça do Estado do Ceará concluiu que não se demonstrou o excesso de prazo na complexa tramitação do processo penal, nem a responsabilidade funcional dos juízes que o presidiram.

Nesse ponto vale a pena apontar que a Corte Interamericana condenou o Brasil e concluiu no sentido de que "o processo não é complexo", “a demora do processo se deveu unicamente à conduta das autoridades judiciais" e "o prazo em que se desenvolveu o procedimento penal no caso sub judice não é razoável”, conclusões diametralmente opostas àquelas obtidas no procedimento disciplinar posteriormente promovido, em uma evidente demonstração da diferença das racionalidades utilizadas na análise de cada instância.

Em razão do que foi exposto a respeito da teoria dos sistemas, parece mais adequado sugerir que o Sistema Interamericano de Proteção de Direitos Humanos e o sistema jurídico brasileiro são dois sistemas distintos e autônomos, uma vez que possuem regras e racionalidades diferentes, possuem limites próprios e se diferenciam do seu entorno e entre si. Alguns sustentam posição semelhante, ${ }^{22}$

${ }^{21}$ CORTE INTERAMERICANA DE DIREITOS HUMANOS. Caso Ximenes Lopes contra Brasil (Sentença de 4 de julho de 2006, par. 195 et. seq.).

${ }^{22}$ PEREIRA, Luis Cezar Ramos. Ensaio sobre a responsabilidade internacional do Estado e suas consequências no direito internacional. São Paulo: LTr, 2000. p. 199. 
assentada em outras premissas. A partir disso, a experiência brasileira de participação no Sistema Interamericano se mostrou positiva, com importantes avanços no campo dos direitos humanos. As relações travadas pelos dois sistemas devem, para o aprimoramento dessa experiência, ser de interação e não de antinomia. Não interessa ao Estado brasileiro, conforme os fundamentos, objetivos e princípios determinados pelos artigos $1^{\circ}, 3^{\circ}$ e $4^{\circ}$ da Constituição Federal, romper essas relações, negar ou promover violações dos direitos humanos no país.

O desafio que se impõe é o de promover a interação entre os dois sistemas, ao invés de fomentar a antinomia ou a rivalidade entre eles. Uma proposição que pode colaborar com a interação entre os dois sistemas é a edição de normas que regulamentam o cumprimento das decisões da Corte Interamericana de Direitos Humanos, possibilitando algum grau de harmonização das diferenças entre os dois sistemas e, assim, a melhor comunicação entre eles. Os conflitos que porventura surjam seriam mais bem resolvidos pela compatibilização das lógicas ou racionalidades envolvidas, buscando uma "linguagem" comum a eles, que pelas soluções tradicionais de regras de hierarquia entre normas e órgãos. ${ }^{23}$

\section{Relações entre o sistema interamericano de direitos humanos e o direito brasileiro}

As relações entre o Direito Internacional e o Direito interno são comumente classificadas em duas correntes: o monismo e o dualismo. O monismo defende que as normas internacionais e as normas internas formam um único ordenamento jurídico e se encontram integradas a ele, um sistema fundado no princípio da subordinação, pois todas as normas se encontrariam subordinadas umas às outras. ${ }^{24}$

${ }^{23}$ FISCHER-LESCANO, Andreas; TEUBNER, Gunther. Regime-collisions: the vain search for legal unity in the fragmentation of global law. Michigan Journal of International Law, Ann Arbor, v. 25, n. 4, p. 45-46, 2004.

${ }^{24}$ FRAGA, Mirtô. O conflito entre tratado internacional e norma de direito interno. Rio de Janeiro: Forense, 1998. p. 7. 
As concepções monistas, por sua vez, dividiram-se em duas vertentes. A primeira delas defende a unidade da ordem jurídica sob a prevalência das regras internacionais ${ }^{25}$ e foi criticada sob os argumentos de que não corresponde à História (que aponta que o Estado é anterior ao Direito Internacional), não se coaduna com o conceito de soberania estatal e não observa a independência entre as ordens jurídicas interna e internacional (pois um ato interno só pode ser revogado por outro ato interno). ${ }^{26}$ A segunda, de cunho nacionalista, ao tempo em que defende a ordem jurídica única, formada pelas normas internacionais e internas, sustenta o primado daquelas de índole nacional de cada Estado soberano, que tem a faculdade de adotar ou não as regras internacionais. É dada especial importância à soberania de cada Estado e a sua constituição, como parâmetro jurídico maior e como medida à importância que as normas internacionais terão naquele ordenamento interno. As objeções à segunda vertente do monismo versam sobre os argumentos de que as obrigações internacionais não se fundam nas constituições estatais, uma vez que os compromissos internacionais não são rompidos em caso da promulgação de nova constituição. ${ }^{27}$

Por ter como fundamento a ideia de que o Direito Internacional e o Direito interno formam uma só unidade jurídica, a assinatura e ratificação de um compromisso internacional já significam a sua validade e vigência em relação aos seus aspectos internos, não dependendo da edição de outro ato ou norma para produzir efeitos sobre as pessoas, bens e relações jurídicas travadas em um Estado. Ambos, tanto o Direito Internacional quanto o Direito interno, estariam aptos a reger essas relações entre os indivíduos. ${ }^{28}$ As normas do Direito Internacional e do Direito interno se prestariam, segundo os monistas, a regular situações distintas, não havendo que se falar em conflito entre elas. O primeiro disciplina as relações entre os sujeitos de Direito Internacional Público, enquanto o segundo, as questões internas do Estado. ${ }^{29}$

${ }^{25}$ CASSESE, Antonio. International Law. New York: Oxford University, 2001. p. 164.

${ }^{26}$ FRAGA, Mirtô. O conflito entre tratado internacional e norma de direito interno. Rio de Janeiro: Forense, 1998. p. 8-9.

${ }^{27}$ FRAGA, Mirtô. O conflito entre tratado internacional e norma de direito interno. Rio de Janeiro: Forense, 1998. p. 7.

${ }^{28}$ MAZZUOLI, Valério de Oliveira. Curso de direito internacional público. 2. ed. rev. atual. e ampl. São Paulo: Revista dos Tribunais, 2007. p. 59.

${ }^{29}$ MAZZUOLI, Valério de Oliveira. Curso de direito internacional público. 2. ed. rev. atual. e ampl. São Paulo: Revista dos Tribunais, 2007. p. 54. 
Para os dualistas, o Direito Internacional e o Direito interno de cada Estado são sistemas independentes e distintos, de tal modo que as normas internas não guardam qualquer relação de validade jurídica com a ordem internacional. Defendem a diversidade das fontes de produção das normas jurídicas, observando que a norma internacional somente opera efeitos no âmbito interno de um Estado quando recepcionada por ele, ou seja, quando houver sido aceita e introduzida no seu ordenamento doméstico. ${ }^{30}$

Ocorre que não há um regramento uniforme a respeito da obrigatoriedade das normas internacionais nos ordenamentos jurídicos internos, o que faz com que, consequentemente, cada Estado decida como as normas internacionais se tornam vinculantes no país e qual a sua relação com as normas internas. ${ }^{31}$ No Brasil, o Supremo Tribunal Federal apresenta entendimento no sentido de que os tratados, em regra, ingressam no ordenamento jurídico brasileiro no mesmo nível da legislação interna, com força de norma infraconstitucional. ${ }^{32} \mathrm{O}$ tratado deve ser entendido como uma fonte de direito distinta da lei, que não se torna lei nacional nem tem força de lei ordinária ou complementar. ${ }^{33}$ Quando o tratado é autoaplicável, ou seja, não depende da produção de outras normas internas para gerar efeitos jurídicos, desde o julgamento, em 1977, do Recurso Extraordinário n 80.004/SE, o STF entende que o tratado revoga a lei interna anterior a ele, resolvendo a questão por lex posterior derogat priori, tendo por premissa a equivalência hierárquica entre eles. Na Ação Direta de Inconstitucionalidade $n^{\circ} 1480 / D F$, por sua vez, o STF decidiu que os tratados não podem atuar como sucedâneo da lei complementar exigida pela Constituição, pois a Resolução n ${ }^{\circ} 158$ da OIT não era autoaplicável e a Constituição brasileira exigia a regulamentação da matéria por lei complementar.

Como já exposto anteriormente, quanto a tratados sobre o tema dos direitos humanos, há dois procedimentos previstos no ordenamento jurídico brasileiro e é possível que esses instrumentos ocupem posição hierárquica constitucional ou

\footnotetext{
${ }^{30}$ REZEK, Francisco. Direito internacional púbico: curso elementar. 11. ed. rev. e atual. São Paulo: Saraiva, 2008. p. 4-5.

${ }^{31}$ CASSESE, Antonio. International Law. New York: Oxford University, 2001. p. 168.

32 VARELLA, Marcelo D. Direito internacional público. São Paulo: Saraiva, 2009. p. 67.

${ }^{33}$ VARELLA, Marcelo D. Direito internacional público. São Paulo: Saraiva, 2009. p. 69.
} 
infraconstitucional, de acordo com o rito que observarem. Corroborando o entendimento de que o Sistema Interamericano de Direitos Humanos e o Direito brasileiro são dois sistemas distintos e autônomos, é possível verificar que a forma de recepção das normas brasileiras parece inclinar-se mais ao dualismo, uma vez que os instrumentos internacionais não têm aplicação automática e imediata no país. É necessário observar alguns procedimentos para que um tratado seja aplicável internamente.

Ainda não ficou claramente definida, nos julgados do STF, a questão sobre a primazia do Direito interno ou do Direito Internacional no Brasil. A partir de 1977 até mais recentemente, o STF adotava o entendimento do status infraconstitucional da Convenção Americana sobre Direitos Humanos - Pacto de San José da Costa Rica. Tal como exposto no Habeas Corpus n 72131/RJ, o Pacto de San José era afastado, para considerar constitucional a prisão do depositário infiel, fundada no art. 1.287 do Código Civil de 1916 e no Decreto-Lei n ${ }^{\circ}$ 911, de $1^{\circ}$ de outubro de 1969. Ainda que posterior, o Pacto não havia derrogado essas normas, por se tratar de disposições especiais, em face das normas gerais previstas no tratado. O Pacto era visto como verdadeira limitação ao mandamento constitucional do inc. LXVII do art. $5^{\circ}$ da Constituição.

A partir do julgamento conjunto dos Recursos Extraordinários n $466343 \mathrm{e}$ $n^{\circ} 349703$ e dos Habeas Corpus no 87585 e n 92566 , que tratavam igualmente do tema da prisão civil do depositário infiel, tal como expresso no voto do Ministro Gilmar Mendes, o STF alterou o entendimento até então sustentado, explicitando que os tratados anteriores à Emenda n ${ }^{\circ} 45$, de 2004 não poderiam ser comparados às normas constitucionais. Porém, a Emenda indicou o caráter diferenciado dos tratados no ordenamento jurídico brasileiro, conferindo-lhe posição privilegiada, e abandonando a tese do status legal dos tratados, adotada pelo STF desde 1977. O Ministro entendeu que deveria ser reconhecida a estatura supralegal dos tratados de direitos humanos, demonstrando a tendência do constitucionalismo contemporâneo de prestigiar essas normas e indicando que a jurisprudência do STF deveria ser revista, para lhes conferir a supralegalidade sem status constitucional. Os tratados não poderiam ferir a supremacia da Constituição, estariam sujeitos ao controle de constitucionalidade e ocupariam uma posição especial no ordenamento. 
Foram proferidos alguns votos contrários. Em 12 de março de 2008, o Ministro Celso de Mello votou no sentido da liberdade do legislador ordinário em regular as hipóteses de prisão civil e da necessidade de reavaliação das premissas teóricas que fundamentavam o seu entendimento anterior. Acolheu o Ministro a orientação que atribui natureza constitucional aos tratados de direitos humanos, em três situações distintas: tratados celebrados em momento anterior à Constituição de 1988 foram recepcionados pelo $\$ 2^{\circ}$ do art. $5^{\circ}$ em status constitucional; tratados celebrados entre a promulgação da Constituição de 1988 e a Emenda $n^{\circ}$ 45, de 2004 assumem caráter materialmente constitucionais, devendo ser incluídos no bloco de constitucionalidade - somatória daquilo que se soma à Constituição escrita, em função dos valores e princípios nela consagrados, que funciona como parâmetro para o exame de constitucionalidade das normas inferiores - e tratados que venham a ser celebrados após a Emenda n 45, de 2004 terão natureza constitucional se obedecerem ao rito das emendas constitucionais.

Ao final, contudo, prevaleceu o entendimento explicitado pelo Ministro Gilmar Mendes de que o tratado sobre direitos humanos não precisa "[...] ser aplicado na estrutura de outro normativo interno nem ter status paritário com qualquer deles, pois tem assento próprio na Carta Magna, com requisitos materiais e formais peculiares" (Aditamento ao Voto no RE 466343). ${ }^{34}$ Assim, segundo as decisões mais atuais do STF, a Convenção Americana sobre Direitos Humanos ingressa no ordenamento jurídico com nível hierárquico supralegal, condicionando toda a legislação infraconstitucional, porém com observância às limitações impostas pela Constituição.

Há autores que consideram que, no julgamento da Ação Direta de Inconstitucionalidade (ADI) $n^{\circ} 3510 / \mathrm{DF}$, houve uma mudança no entendimento acima apresentado e, assim, um retorno à posição antiga do Tribunal. A ADI n ${ }^{\circ} 3510 /$ DF versa sobre o artigo $5^{\circ}$ da Lei $n^{\circ} 11.105$, de 24 de março de 2005, que autoriza e disciplina as pesquisas com células-tronco embrionárias. No seu julgamento, os Ministros do STF trataram do artigo $4^{\circ}$ (1) da Convenção Americana sobre

${ }^{34}$ Voto constante do sítio do Supremo Tribunal Federal na Internet. Disponível em: <www. stf.jus.br>. Acesso em: 31 jan. 2010. 
Direitos Humanos, que dispõe sobre o direito à vida, que deve ser protegido pela lei e, em geral, desde o momento da concepção. O Ministro Celso de Mello salientou, em seu voto, que a Comissão Interamericana de Direitos Humanos, no Caso "Baby Boy" (Resolução n 23/81), entendeu que a Convenção Americana "não acolheu nem estabeleceu um conceito absoluto do direito à vida desde o momento da concepção", em razão da inclusão da cláusula "em geral” no dispositivo. Após a prolação do voto do Ministro Celso de Mello, instalou-se um momento de debate entre os Ministros presentes e eles concordaram que a expressão "em geral" foi aposta ao dispositivo na conferência diplomática que promoveu a sua redação para que possibilitasse a previsão de exceções à regra de proteção da vida desde a concepção.

Nesse caso, parece mais adequado entender que o STF não alterou o entendimento mais recente sobre o Pacto de San José da Costa Rica, de que ele possui nível hierárquico supralegal, porém infraconstitucional no Direito brasileiro, explicitado no julgamento do Recurso Extraordinário n ${ }^{\circ} 66343$. De fato, os Ministros reconheceram que a redação do artigo $4^{\circ}(1)$ do Pacto comporta exceções à regra nela contida em razão da sua própria redação (pela expressão "em geral"), e essas exceções podem ser previstas pelas leis internas, tal como os exemplos contidos no artigo 128, incisos I e II do Código Penal pátrio. Assim, esse entendimento não trasladou o Pacto da estatura reconhecida no julgamento do Recurso Extraordinário $n^{\circ} 466343$ para a equivalência à legislação interna, mas indicou que, de fato, não havia conflito entre o artigo 4 (1) do Pacto e a legislação interna brasileira, pois esta, de posição hierárquica inferior, estava autorizada pela exceção prevista no diploma internacional, mantido em sua posição hierárquica supralegal.

Desse modo, verifica-se que foi criada uma categoria diferenciada para os tratados de direitos humanos posteriores à promulgação da Constituição Federal de 1988, porém anteriores à Emenda Constitucional $n^{\circ} 45$, de 2004 , que previu um procedimento especial de aprovação desse tipo de instrumento internacional. A Constituição Federal de 1988, as emendas constitucionais e os tratados que versem sobre matéria de direitos humanos aprovados segundo o rito previsto no $\$ 3^{\circ}$ do artigo $5^{\circ}$ da Constituição brasileira, a exemplo da Convenção Internacional sobre 
os Direitos da Pessoa com Deficiência e seu Protocolo Facultativo, ${ }^{35}$ possuem a mesma estatura constitucional, integram o bloco de constitucionalidade, sujeitam-se à mesma disciplina jurídica e, assim, servem de parâmetro para o controle de constitucionalidade das normas inferiores.

Dentro de uma estrutura hierárquica, logo abaixo dessas normas, encontra-se esse tipo normativo autônomo novo, criado pela jurisprudência do Supremo Tribunal Federal nas decisões sobre a Convenção Americana sobre Direitos Humanos, que consiste em tratados de direitos humanos aprovados antes da vigência da Emenda Constitucional n 45 , de 2004. Esse tipo normativo possui estatura supralegal e, assim, informa toda a legislação que se encontra abaixo dele, porém infraconstitucional, observando as limitações impostas pelas normas constitucionais.

Por fim, em posição hierarquicamente inferior, estão a legislação complementar e ordinária e os tratados que não versam sobre temas de direitos humanos. Ainda não houve caso de tratado de direitos humanos aprovado após a vigência da Emenda Constitucional $n^{\circ} 45$, porém não submetido ao rito previsto no $\$ 3^{\circ}$ do artigo $5^{\circ}$ da Constituição. A Convenção sobre os Direitos das Pessoas com Deficiência foi aprovada já pelo rito previsto para as emendas constitucionais, de acordo com o dispositivo acima invocado, e foi promulgada pelo Presidente da República por meio do Decreto $n^{\circ}$ 6.949, de 25 de agosto de 2009. Pela clareza da disposição constitucional que previu rito diferenciado para que um tratado de direitos humanos tenha força de norma constitucional, imagina-se que, se não aprovado dessa forma, o tratado terá a mesma estatura da legislação infraconstitucional.

Em face do que foi apresentado a respeito das atuais decisões do Supremo Tribunal Federal sobre a posição dos tratados de direitos humanos no ordenamento jurídico brasileiro, a Convenção Americana sobre Direitos Humanos ocupa posição de relevância no Direito brasileiro, o que corrobora a imperatividade dos compromissos por meio dela assumidos. Considerando o quanto exposto, na hipótese de condenação pela Corte Interamericana, declarando a responsabilidade do

${ }_{35}$ Promulgados pelo Presidente da República por meio do Decreto $n^{\circ} 6.949$, de 25 de agosto de 2009. 
Estado brasileiro por violação de direitos humanos, resta evidente a importância do tema em face da estatura do Pacto de San José da Costa Rica no plano interno.

À vista do entendimento da supralegalidade da Convenção no ordenamento jurídico pátrio, é possível vislumbrar algumas situações de potencial conflito no cumprimento das decisões emanadas da Corte Interamericana. Caso a decisão internacional signifique afronta a uma norma integrante da legislação infraconstitucional, ordinária ou complementar, parece que o entendimento do Supremo seguiria no sentido do afastamento da legislação interna, em prestígio à sentença internacional.

Os conflitos mais eloquentes poderiam ocorrer se a decisão da Corte Interamericana, em algum dos seus pontos resolutivos, desafiasse normas de índole constitucional. No tema da responsabilidade estatal e de agentes públicos, por exemplo, poderia a sentença internacional contrariar a coisa julgada, determinando a responsabilização internacional do Estado brasileiro por danos que, perante a jurisdição interna, não foram atribuídos a ente estatal ou seus agentes, razão pela qual a sentença interna afastou a responsabilidade do Estado e de seus agentes. Haveria hierarquia entre as instâncias jurisdicionais internacional e interna?

Não é possível afirmar a primazia do Direito Internacional sobre o Direito brasileiro ou vice-versa. As relações entre eles são complexas e isso reforça as dúvidas em torno da solução jurídica que será dada ao conflito material entre os conteúdos das decisões da Corte Interamericana de Direitos Humanos e do Supremo Tribunal Federal, no pronunciamento sobre a aplicação da Lei de Anistia brasileira, pois tanto o monismo quanto o dualismo não oferecem resposta satisfatória às questões ora levantadas.

Promovendo-se uma análise hierárquica do problema, à luz do mais recente entendimento do STF sobre a estatura interna dos tratados a respeito dos direitos humanos, poder-se-ia afirmar que deveria prevalecer a decisão da Corte Interamericana de Direitos Humanos em conflito com a legislação infraconstitucional brasileira, porém nunca em face da Constituição Federal de 1988. Os tribunais internos reafirmariam a supremacia da constituição brasileira sobre as normas inter- 
nacionais e afastariam os efeitos da decisão da Corte Interamericana, o que geraria o descumprimento da obrigação assumida internacionalmente perante o Sistema Interamericano e a OEA, podendo o país sofrer as sanções previstas na Carta da OEA, dentre elas, a exclusão. Ainda, ao Brasil poderia ser atribuída a reputação internacional de um país que não cumpre os seus acordos e viola direitos humanos, indesejada para os países no cenário mundial. Basta observar como eles se mobilizaram para ajudar o Haiti, depois da destruição provocada pelo terremoto ocorrido em janeiro de 2010, motivados principalmente pela solidariedade e também, de forma subjacente, pelo desejo de gozar de boa imagem perante os seus pares.

Seria o pior dos cenários o rompimento do país com o Sistema Interamericano de Direitos Humanos. Há experiências exitosas relativas a casos que tramitaram perante os órgãos do Sistema Interamericano, como o Caso Maria da Penha e o Caso dos Meninos Emasculados do Maranhão, nos quais foram firmados acordos de solução amistosa que representaram algumas mudanças significativas na vida das vítimas. O primeiro teve reflexos não apenas na vida da vítima que lhe dá o nome, mas também no arcabouço de proteção às mulheres contra a violência doméstica e familiar no país, com a edição da Lei ${ }^{\circ}$ 11.340, de 7 de agosto de 2006. Os órgãos do Sistema Interamericano reconhecem quando o Estado empreende esforços efetivos para a cessação das violações de direitos humanos ${ }^{36} \mathrm{e}$ esse reconhecimento serve de estímulo à promoção de políticas públicas na área. É fundamental que o Brasil participe do Sistema Interamericano e promova os aprimoramentos necessários, impulsionado pelas decisões internacionais. Diante disso, é preciso buscar meios e instrumentos que possibilitem uma interação mais pacífica entre o sistema jurídico brasileiro e o Sistema Interamericano de Proteção, ao invés de fomentar a antinomia ou a rivalidade entre eles. Talvez seja possível

${ }^{36}$ Exemplo de reconhecimento da Corte Interamericana de Direitos Humanos são as decisões que levantaram as medidas provisórias decretadas por ela em favor dos internos da Penitenciária "Dr. Sebastião Martins Silveira” em Araraquara e das crianças e adolescentes internos do "Complexo do Tatuapé" da FEBEM, ambos em São Paulo. CORTE INTERAMERICANA DE DIREITOS HUMANOS. Pessoas Privadas de Liberdade na Penitenciária "Dr. Sebastião Martins Silveira” em Araraquara, São Paulo (Resolução de 25 de novembro de 2008). CORTE INTERAMERICANA DE DIREITOS HUMANOS. Crianças e Adolescentes Privados de Liberdade no "Complexo do Tatuapé" da FEBEM (Resolução de 25 de novembro de 2008). 
buscar aproximá-los nas suas diferenças, naquilo em que são distintos: racionalidade, limites, formas de comunicação com o entorno e normas.

\section{Decisões estrangeiras, decisões internacionais e direito interno}

No Brasil, apenas as decisões estrangeiras possuem uma regulamentação quanto à produção de efeitos no país; elas são submetidas ao procedimento de homologação pelo Superior Tribunal de Justiça, a teor do artigo 105, inciso I, alínea "i" da Constituição Federal de 1988. ${ }^{37}$ Nesse procedimento, são observados os requisitos previstos na Resolução ${ }^{\circ}$ 9, de 4 de maio de 2005, do Superior Tribunal de Justiça. Desse modo, o ordenamento jurídico brasileiro disciplina o modo de "ingresso" das decisões estrangeiras e delimita o seu conteúdo e seus efeitos no sistema, possibilitando que o que estava no entorno - decisão estrangeira - entre efetivamente no sistema nacional.

Ainda que distinto dos demais, o sistema jurídico brasileiro estabeleceu formas de interação com os sistemas jurídicos estrangeiros, selecionando as relações que com eles pode travar. Conforme dispõe o artigo $6^{\circ}$ da Resolução n ${ }^{\circ} 9$, de 2005, não podem ser homologadas, por exemplo, as decisões estrangeiras que ofendem a soberania ou a ordem pública brasileira, a critério das autoridades competentes nacionais, servindo esse parâmetro como uma espécie de filtro para permitir ou não a entrada da decisão estrangeira no ordenamento jurídico brasileiro.

As decisões internacionais, a seu turno, não são passíveis de homologação por órgão integrante do sistema jurídico brasileiro e, a rigor, não precisariam de quaisquer normas que disciplinem o seu ingresso no ordenamento brasileiro, pois elas já fazem parte dele, por serem prolatadas por órgão da estrutura de um organismo internacional do qual o Brasil faz parte. Assim, em poucas palavras, decisão estrangeira é aquela prolatada por órgão integrante da estrutura institucional de outro Estado e tem seu fundamento no Direito estrangeiro e decisão internacional,

\footnotetext{
${ }^{37}$ MAZZUOLI, Valério de Oliveira. Curso de direito internacional público. 2. ed. rev. atual. e
} ampl. São Paulo: Revista dos Tribunais, 2007. p. 736. 
por sua vez, é aquela emanada de tribunal internacional que tem jurisdição sobre o Estado-parte no processo internacional e possui amparo no Direito Internacional.

Quando o Brasil é notificado de uma decisão advinda da Corte Interamericana de Direitos Humanos, não há normas que prevejam expressa e especificamente o procedimento para o seu cumprimento, as autoridades e órgãos competentes para a realização dos atos de execução e a distribuição interna das responsabilidades, o que pode gerar dúvidas e questionamentos sobre esses pontos e atrapalhar ou até impedir que a decisão alcance plenamente seus efeitos. Atualmente, participam da execução das sentenças da Corte Interamericana o Ministério das Relações Exteriores, a Secretaria de Direitos Humanos da Presidência da República e a Advocacia-Geral da União, todos os órgãos do Poder Executivo da União.

Foi firmado, no ano de 2006, um Acordo de Cooperação Técnica entre o Ministério da Justiça, a Secretaria de Direitos Humanos da Presidência e o Conselho Nacional de Justiça (CNJ), com o objetivo de promover uma articulação entre esses órgãos para dar maior celeridade à tramitação de casos no Poder Judiciário, relacionados a processos que se encontrem sob o exame de órgãos internacionais. A Corregedoria Nacional de Justiça do CNJ lançou, em 23 de novembro de 2010, o programa Justiça Plena, com o objetivo de monitorar o andamento de processos de grande repercussão social que estão com o andamento paralisado no Judiciário Brasileiro. A Secretaria de Direitos Humanos da Presidência da República atua em parceria com o $\mathrm{CNJ}$ nesse programa e já indicou dez processos que tramitam no Sistema Interamericano de Proteção de Direitos Humanos para serem o piloto do programa. Dentre os processos indicados, estão as ações judiciais relativas ao Caso Ximenes Lopes. Essa iniciativa certamente corrobora os esforços de alguns órgãos e instituições brasileiras para dar cumprimento às determinações de apuração e punição dos responsáveis pelas violações de direitos humanos reconhecidas pela Corte. Ao que parece, a intenção dessas medidas é integrar os órgãos do Poder Judiciário ao procedimento de execução das sentenças da Corte Interamericana de Direitos Humanos, capazes de atuar em um ponto fundamental, presente em todas as sentenças e demandas internacionais em trâmite em face do Brasil: a violação dos artigos da Convenção Americana relativos às garantias judiciais e à proteção judicial (artigos 8 e 25), em face da denegação de justiça no caso concreto. A seu 
turno, os órgãos do Poder Legislativo ainda não fazem parte desse procedimento, não tendo participado do cumprimento das sentenças condenatórias proferidas contra o Brasil até o presente momento.

A dúvida quanto à competência e a ausência da previsão de um procedimento e de instrumentos mais específicos atuam, no mais das vezes, em desfavor da efetividade dos comandos condenatórios das decisões internacionais, seja pela inércia de alguns órgãos e instituições, seja pela negativa de competência de outros, seja pela negativa de responsabilidade de outros. Normas que consigam dirimir essas situações parecem tornar a atuação estatal mais ágil e efetiva nesse ponto.

Não há uma regulamentação sobre o cumprimento de decisões internacionais no Brasil, diferente do que ocorre em outros países da América Latina, como Colômbia, Peru, Honduras, Venezuela e Costa Rica, ${ }^{38}$ nos quais foram editadas normas que disciplinam a execução das resoluções internacionais. A edição de normas desse tipo se insere na obrigação dos países de adotarem disposições internas, legislativas ou de outra natureza, específicas sobre o tema ou não, tal como disposto no artigo $2^{\circ}$ da Convenção Americana sobre Direitos Humanos. Serão tratadas, a seguir, as medidas adotadas por alguns países em relação a essa matéria.

Colômbia. A Lei $n^{\circ} 288$, de 5 de julho de 1996 criou mecanismo que obriga o Governo Nacional a pagar indenizações em cumprimento às decisões da Comissão Interamericana de Direitos Humanos. Tal mecanismo prevê a atuação de um Comitê de Ministros, integrado pelos titulares das pastas do Interior, das Relações Exteriores, da Justiça e do Direito e da Defesa Nacional, que deve proferir um parecer em relação ao cumprimento da decisão do órgão internacional de direitos humanos, no prazo de 45 dias, a contar do seu pronunciamento. Em caso de manifestação favorável e presentes outros requisitos, descritos na lei, inicia-se uma

\footnotetext{
${ }^{38}$ PIOVESAN, Flávia. Implementation through intrastate levels of government, including federal, state/provincial and municipal jurisdictions. In: Working session on the implementation of international human rights obligations and standards in the Inter-American System, 2003, Washington. Anais eletrônicos... Washington: Comissão Interamericana de Direitos Humanos, 2003. Disponível em: <www. internationaljusticeproject.org/pdfs/Piovesan-speech.pdf>. Acesso em: 31 jan. 2010.
} 
conciliação, que observa parâmetros internos, como provas produzidas em processos judiciais e administrativos nacionais, mas também, especialmente, as provas valoradas pela instância internacional na decisão.

O título obtido ao fim da conciliação produz os mesmos efeitos do crédito reconhecido judicialmente e da coisa julgada e, segundo a Lei ${ }^{\circ} 288$, de 1996 , estende os seus efeitos sobre todos os processos em curso contra o Estado em relação aos fatos objeto da conciliação e da decisão internacional. Nos termos do artigo 11 da Lei, caso não seja obtido um acordo por meio do procedimento de conciliação nela descrito, os interessados podem ingressar com um pedido de liquidação de danos junto ao tribunal contencioso administrativo competente, seguindo o rito previsto na legislação processual colombiana.

O artigo 12 da Lei $\mathrm{n}^{\circ}$ 288, de 1996, determina que as indenizações pagas conforme o rito previsto na norma referida dão lugar à ação de repetição ou ação de regresso, prevista no artigo 90 da Constituição colombiana. Tal como no ordenamento jurídico brasileiro, a responsabilidade do Estado pelos danos causados pelos atos praticados por seus agentes tem assento constitucional ${ }^{39}$ na Colômbia, bem como a respectiva ação para reaver do agente o que foi pago, responsabilizando-o na esfera civil.

Curiosamente, a Lei no 288, de 1996, trata apenas do cumprimento de determinações advindas da Comissão Interamericana de Direitos Humanos, sem mencionar aquelas proferidas pela Corte Interamericana. Alguns ${ }^{40}$ defendem que a lei pode ser aplicada por analogia à execução das decisões do mencionado Tri-

\footnotetext{
${ }^{39}$ Artículo 90. El Estado responderá patrimonialmente por los daños antijurídicos que le sean imputables, causados por la acción o la omisión de las autoridades públicas.

En el evento de ser condenado el Estado a la reparación patrimonial de uno de tales daños, que haya sido consecuencia de la conducta dolosa o gravemente culposa de un agente suyo, aquél deberá repetir contra éste.

40 TRINDADE, Otávio Augusto Drummond Cançado. Os efeitos das decisões dos tribunais internacionais de direitos humanos no direito interno dos Estados. In: LEÃO, Renato Zerbini Ribeiro. (Coord.). Os rumos do direito internacional dos direitos humanos: ensaios em homenagem ao Professor Antônio Augusto Cansado Trindade. Porto Alegre: S. A. Fabris, 2005. p. 309.
} 
bunal, pois se ela é aplicável a decisões de órgão político, de natureza facultativa, mais razão há para adotá-la no caso do cumprimento de decisões jurisdicionais internacionais, de cumprimento obrigatório.

Peru. Inicialmente, a Lei de Habeas Corpus e Amparo, de ${ }^{\circ} 23506$, de 8 de dezembro de 1982, possuía um título dedicado à jurisdição internacional (Título V), composto de três artigos, no qual estava elencada a Comissão Interamericana de Direitos Humanos como órgão internacional ao qual se poderia recorrer em caso de violação a direitos previstos na Constituição peruana. No seu artigo 40, a Lei citada dispunha que, uma vez submetido o Estado peruano à jurisdição de algum organismo internacional, suas decisões não requeriam, para sua validade e eficácia, reconhecimento, revisão ou exame prévio qualquer, determinando que a Corte Suprema de Justiça deveria receber as decisões internacionais e proceder a sua execução e seu cumprimento, em conformidade com as normas e procedimentos internos vigentes sobre execução de sentença.

Essa norma foi revogada pela Lei $\mathrm{n}^{\circ} 27.775$, de 27 de junho de 2002, que expressamente "regula o procedimento de execução de sentenças emitidas por tribunais supranacionais". O seu artigo $2^{\circ}$ trata do procedimento aplicável à execução de decisões que contenham condenação ao pagamento de uma soma em dinheiro, a título indenizatório pelos danos causados à vítima. Os artigos $3^{\circ} \mathrm{e} 4^{\circ}$ versam sobre decisões que dispõem a respeito de medidas não indenizatórias. Está previsto também o direito de regresso do Estado em face do agente público responsável pela conduta que deu causa à prolação da decisão internacional no artigo $5^{\circ}$. Essa lei deve ser considerada em conjunto com a Lei n 28.237 , que dispõe sobre o Código Processual Constitucional e, no seu Título X, trata das hipóteses de jurisdição internacional. O procedimento de execução das decisões da Corte Interamericana é entregue principalmente a órgãos do Poder Judiciário do país, o que determina o seu engajamento nessa tarefa, já superando problemas a isso relacionados. ${ }^{41}$

\footnotetext{
${ }^{41}$ KRSTICEVIC, Viviana. Reflexões sobre a execução das decisões do Sistema Interamericano de Proteção dos Direitos Humanos. In: CENTRO PELAJUSTIÇA E O DIREITO INTERNACIONAL (Org.) Implementação das decisões do Sistema Interamericano de Direitos Humanos: jurisprudência, instrumentos normativos e experiências nacionais. Rio de Janeiro: CEJIL, 2009. p. 71-72.
} 
Honduras. O artigo 15 da Constituição de 1982 de Honduras determina que é válida e obrigatória a execução das decisões arbitrais e judiciais de natureza internacional.

Venezuela. Igualmente a Venezuela, pelo disposto no artigo $31^{42}$ da sua Constituição, de 1999, está obrigada a adotar as medidas que sejam necessárias para dar cumprimento às decisões advindas de órgãos internacionais.

Costa Rica. Tem-se notícia de que a Costa Rica firmou com a Corte Interamericana de Direitos Humanos um acordo de sede, por meio do qual o país se comprometeu a dar a mesma disciplina prevista para as decisões emitidas pelo seu Poder Judiciário às sentenças prolatadas pela Corte que tenham sido comunicadas às autoridades administrativas e judiciais do referido país. ${ }^{43}$

Argentina. Já foram elaborados vários projetos de lei na Argentina, com o objetivo de disciplinar o cumprimento das decisões advindas do Sistema Interamericano de Direitos Humanos, tanto da Comissão quanto da Corte. Algumas propostas previam um órgão formado por ministros de Estado com competência para dar cumprimento às decisões da Comissão Interamericana, semelhante ao disposto na Lei $\mathrm{n}^{\circ} 288$, de 1996, da Colômbia. Outras propuseram um procedimento de conciliação, tal como a legislação do Peru já apresentada. Alguns projetos previram que, quando a violação de direitos humanos for imputada a uma província, ela será notificada pelo governo federal para dar cumprimento à decisão no prazo assinalado, sob pena de que os próprios órgãos federais deem cumprimento aos pontos

\footnotetext{
${ }^{42}$ Artículo 31. Toda persona tiene derecho, en los términos establecidos por los tratados, pactos $y$ convenciones sobre derechos humanos ratificados por la República, a dirigir peticiones o quejas ante los órganos internacionales creados para tales fines, con el objeto de solicitar el amparo a sus derechos humanos.

El Estado adoptará, conforme a procedimientos establecidos en esta Constitución y la ley, las medidas que sean necesarias para dar cumplimiento a las decisiones emanadas de los órganos internacionales previstos en este artículo.

${ }^{43}$ KRSTICEVIC, Viviana. Reflexões sobre a execução das decisões do Sistema Interamericano de Proteção dos Direitos Humanos. In: CENTRO PELAJUSTIÇA E O DIREITO INTERNACIONAL (Org.) Implementação das decisões do Sistema Interamericano de Direitos Humanos: jurisprudência, instrumentos normativos e experiências nacionais. Rio de Janeiro: CEJIL, 2009. p. 68.
} 
resolutivos internacionais e depois apurem as responsabilidades da omissão da unidade federada. Há também a previsão da possibilidade de o governo nacional, agindo em adimplemento de decisão em que foi reconhecida violação de direitos humanos de responsabilidade de outro ente federado, promover a repetição dos valores que pagou às vítimas, caso o ente assim não o faça. $\mathrm{O}$ direito à repetição existe tanto em face da pessoa jurídica de direito público quanto do agente público responsável pela conduta. Os projetos de lei elaborados por parlamentares argentinos têm muitos pontos positivos, porém não se tem notícia da aprovação de qualquer um deles até o momento. ${ }^{44}$

Normas desse tipo, conhecidas por enabling legislation, permitem que os sistemas internacional e interno interajam de forma mais coordenada, menos conflituosa ou duvidosa, possibilitando a disciplina do meio de comunicação entre eles. Algumas questões que causam empecilhos à execução de sentenças internacionais, na prática, podem ser reguladas por essas normas, tais como autoridades responsáveis pelo cumprimento da sentença e seu monitoramento, delimitação de responsabilidades pelas reparações materiais e pelas medidas não pecuniárias às vítimas, inclusive pelas medidas de não repetição das condutas violadoras de direitos humanos, e procedimentos a serem observados, que podem seguir a regra geral ou ter disciplina especial.

Elas podem, ainda, prever a participação de órgãos do Judiciário e do Legislativo no cumprimento das decisões internacionais, uma vez que esse processo está atualmente centrado em órgãos do Executivo. Essas normas podem facilitar e esclarecer muitas situações que, na sua ausência, dependeriam da interpretação das normas gerais já postas no ordenamento ou seriam dirimidas pelas autoridades administrativas e judiciais, a despeito de se compreender que as normas gerais já contemplam a divisão de competência entre os órgãos e entes públicos.

\footnotetext{
${ }^{44}$ KRSTICEVIC, Viviana. Reflexões sobre a execução das decisões do Sistema Interamericano de Proteção dos Direitos Humanos. In: CENTRO PELAJUSTIÇA E O DIREITO INTERNACIONAL (Org.) Implementação das decisões do Sistema Interamericano de Direitos Humanos: jurisprudência, instrumentos normativos e experiências nacionais. Rio de Janeiro: CEJIL, 2009. p. 73.
} 
As normas que regulam o procedimento interno de execução de decisões internacionais podem, assim, facilitar a participação dos diversos atores públicos no cumprimento dessas sentenças, bem como afastar dúvidas que podem paralisar seu andamento regular, porém não são garantia de que essas decisões serão integralmente cumpridas. Observa-se que o cumprimento das decisões é praticamente integral quanto ao pagamento de indenizações, ao reconhecimento público de responsabilidade, à publicação das sentenças, à concessão de liberdade ou às reformas legislativas, contudo, surgem as dificuldades no adimplemento nos pontos relativos ao dever de investigar e punir os responsáveis pelas violações de direitos humanos e a outras medidas de não repetição. ${ }^{45}$ Muitas vezes, não são necessárias medidas legislativas para promover o cumprimento integral das decisões internacionais sobre matéria de direitos humanos, mas sim uma vontade de natureza política dos órgãos e agentes públicos com competência para o tema, voltada para o compromisso do país com a comunidade internacional. Este não é o tema de estudo ora em análise, porém é importante que sejam apontadas as eventuais fragilidades ou deficiências no escopo normativo da matéria e as propostas para supri-las, para afastar o argumento utilizado muitas vezes da falta de previsão normativa para a atuação desse órgão ou daquela autoridade pública. Assim pode ser posto às claras o peso do compromisso político do Estado com os direitos humanos e, por conseguinte, com o cumprimento das decisões que o responsabilizam internacionalmente.

Brasil. Já foram elaborados alguns projetos envolvendo a temática do cumprimento das decisões emanadas dos órgãos integrantes do Sistema Interamericano de Proteção de Direitos Humanos. No ano de 2000, foi elaborado pelo Deputado Marcos Rolim o Projeto de Lei $n^{\circ} 3.214$, que foi aprovado com uma emenda substitutiva na Comissão de Relações Exteriores e Defesa Nacional em agosto de 2001 e seguiu para apreciação na Comissão de Constituição e Justiça e de Cidadania. Na segunda Comissão, foi apresentado o parecer do seu Relator em dezembro

${ }^{45}$ KRSTICEVIC, Viviana. Reflexões sobre a execução das decisões do Sistema Interamericano de Proteção dos Direitos Humanos. In: CENTRO PELAJUSTIÇA E O DIREITO INTERNACIONAL (Org.) Implementação das decisões do Sistema Interamericano de Direitos Humanos: jurisprudência, instrumentos normativos e experiências nacionais. Rio de Janeiro: CEJIL, 2009. p. 40. 
de 2002, que sugeria a sua aprovação na forma da emenda da Comissão de Relações Exteriores e de Defesa Nacional.

Esse Projeto previa, em seu artigo $1^{\circ}$, que as decisões da Comissão e da Corte Interamericanas de Direitos Humanos produziriam efeitos jurídicos imediatos no ordenamento jurídico brasileiro. O segundo artigo dispunha que as decisões de caráter indenizatório constituiriam títulos executivos judiciais e estariam sujeitas à execução direta contra a Fazenda Pública Federal, tendo natureza alimentícia. Por fim, previa o direito de regresso da União contra aqueles que foram responsáveis direta ou indiretamente pela violação de direitos humanos reconhecida internacionalmente, sejam eles pessoas físicas ou jurídicas, de direito público ou de direito privado.

A emenda substitutiva foi apresentada por entenderem os deputados integrantes das Comissões que a decisão proveniente da Corte Interamericana de Direitos Humanos estava sujeita ao procedimento de homologação previsto para decisões estrangeiras, à época, de competência do Supremo Tribunal Federal. Essa decisão deveria ser considerada formalmente sentença estrangeira e, assim, ser recepcionada segundo o procedimento já indicado. Segundo os pareceres proferidos em ambas as Comissões, entender diversamente significaria ofensa à autonomia e à exclusividade da jurisdição do ordenamento jurídico brasileiro, exercidas pelo Poder Judiciário pátrio. Ocorre que, depois de proferido o parecer do Relator do Projeto na segunda Comissão em 2002, foi arquivado o Projeto de Lei n 3.214 em janeiro de 2003 e, assim, não houve mais a tramitação desse expediente.

Atualmente, está em trâmite no Congresso Nacional brasileiro o Projeto de Lei $\mathrm{n}^{\circ} 4.667$, de 2004, de autoria do Deputado Federal José Eduardo Cardozo, que resgatou o texto do Projeto de Lei $n^{\circ} 3.214$, de 2000, e o repetiu nesse Projeto, ampliando-o para abarcar também decisões advindas dos órgãos da Organização das Nações Unidas. No ano de 2006, no âmbito da Comissão de Direitos Humanos e Minorias, foi apresentado pelo Deputado Federal Orlando Fantazzini um substitutivo que resultara da discussão da matéria na comunidade jurídica ligada aos direitos humanos, tendo sido aprovado na Comissão. Além das disposições constantes do texto original do Projeto, o substitutivo do Deputado Fantazzini 
continha uma disciplina mais detalhada do procedimento de execução das decisões referidas.

No seu artigo $1^{\circ}$, o substitutivo previa ser a União responsável pelas medidas necessárias ao integral cumprimento das decisões e recomendações internacionais, devendo lhes conferir absoluta prioridade. No tocante às obrigações pecuniárias, a União seria responsável pelo pagamento das indenizações às vítimas no prazo de 60 (sessenta) dias, contados da notificação do Estado brasileiro. O seu artigo $3^{\circ}$, tal como a redação original, previa o direito de regresso da União em face dos responsáveis pela conduta ilícita internacional, porém inovava ao autorizar a União a descontar os valores despendidos com o pagamento das reparações previstas nas decisões internacionais do repasse ordinário das receitas destinadas aos entes federativos. Outra inovação do substitutivo era a criação, no artigo $4^{\circ}$, de um órgão com competência para acompanhar a implementação das decisões e recomendações internacionais, bem como das medidas cautelares e das medidas provisórias emitidas pelos órgãos integrantes do Sistema Interamericano de Direitos Humanos. Esse órgão atuaria na articulação entre os diferentes entes federativos e seus Poderes, no acompanhamento das políticas públicas e das ações judiciais relativas às demandas internacionais e na fiscalização do cumprimento das decisões internacionais. Ainda, o órgão possuiria a atribuição de notificar as autoridades competentes, visando o cumprimento das obrigações de fazer e de medidas policiais, judiciais ou o Ministério Público determinadas nas decisões.

O Projeto de Lei seguiu para a análise da Comissão de Relações Exteriores e de Defesa Nacional e lá foi arquivado em janeiro de 2007. Em março de 2007, a pedido do autor do Projeto, ele foi desarquivado e reiniciou-se a sua tramitação na Comissão onde havia sido arquivado. Em novembro de 2007, foi aprovado o parecer do Deputado Relator, Nilson Mourão, que opinou pela aprovação do substitutivo apresentado e já aprovado na Comissão de Direitos Humanos e Minorias. Assim, o Projeto foi encaminhado à Comissão de Constituição e Justiça e de Cidadania e, em 2008, o Deputado Relator Luiz Couto apresentou seu primeiro parecer, em que opinava pela aprovação do Projeto de Lei no seu texto original e pela rejeição do substitutivo apresentado na Comissão de Direitos Humanos e Minorias pelo Deputado Orlando Fantazzini. 
Em 27 de abril de 2010, o Relator Luiz Couto apresentou novo parecer, opinando pela rejeição do substitutivo do Deputado Orlando Fantazzini e apresentando outro substitutivo, mais parecido com o texto original do Projeto, porém com algumas alterações. Segundo o seu andamento processual, o substitutivo apresentado pelo Deputado Luiz Couto foi aprovado pela Comissão de Constituição e Justiça e de Cidadania em 30 de junho deste ano, foi apresentada a sua redação final em 12 de agosto, aprovada em 9 de novembro, e ele foi remetido ao Senado em 18 de novembro. ${ }^{46}$

O Projeto de Lei $n^{\circ} 4.667$, de 2004, na redação do seu atual substitutivo, ${ }^{47}$ possui apenas quatro artigos, sendo um deles relativo à sua vigência. Na redação que ora se apresenta, o Projeto de Lei mencionado é uma iniciativa bastante tímida para resolver os problemas que se apresentam em toda oportunidade em que o Brasil é notificado de uma sentença internacional em seu desfavor. Em primeiro lugar, ele não indica o órgão com atribuição para coordenar o procedimento de execução da decisão, se deve ser um órgão do Executivo ou do Judiciário ou, ainda, um órgão colegiado com representação estatal e da sociedade civil, por exemplo. Não trata também do procedimento, ainda que simplificado, para o trâmite do cumprimento da decisão, incluindo a notificação das autoridades com competência para dar

\footnotetext{
${ }^{46}$ Atualizado até 14 de fevereiro de 2011.

${ }^{47}$ PROJETO DE LEI No 4.667-D DE 2004
}

Dispõe sobre os efeitos jurídicos das decisões dos Organismos Internacionais de Proteção aos Direitos Humanos e dá outras providências.

O CONGRESSO NACIONAL decreta:

Art. $1^{\circ}$ As decisões dos Organismos Internacionais de Proteção aos Direitos Humanos cuja competência for reconhecida pelo Estado brasileiro produzirão efeitos jurídicos imediatos no âmbito do respectivo ordenamento interno.

Art. 2 Caberá ao ente federado responsável pela violação dos direitos humanos o cumprimento da obrigação de

reparação às vítimas dela.

Parágrafo único. Para evitar o descumprimento da obrigação de caráter pecuniário, caberá á União proceder à

reparação devida, permanecendo a obrigação originária do ente violador.

Art. $3^{\circ}$ A União ajuizará ação regressiva contra as pessoas físicas ou jurídicas, de direito público ou privado,

responsáveis direta ou indiretamente pelos atos que ensejaram a decisão de caráter pecuniário.

Art. $4^{\circ}$ Esta Lei entra em vigor na data de sua publicação. 
efetividade aos pontos indicados na condenação, o fluxo das informações, a elaboração dos informes para o órgão internacional e os instrumentos de coerção que possam ser usados internamente. Não previu a redação do substitutivo a execução das obrigações de fazer e não fazer, incluídas nas decisões internacionais a título de medidas de não repetição e de satisfação da vítima da violação de direitos humanos. Não cuidou, ainda, de algumas questões que trazem dificuldades, relativas aos processos de responsabilização daqueles que praticaram o ato ilícito, tais como a possibilidade de reabertura de investigações, a eventual prescrição da pretensão punitiva do Estado na hipótese concreta e a existência de coisa julgada. Diante disso, muitas dificuldades que atualmente são enfrentadas na execução das decisões da Corte Interamericana de Direitos Humanos não serão resolvidas se o Projeto for aprovado com a redação desse substitutivo.

O mérito do substitutivo do Projeto de Lei $\mathrm{n}^{\circ} 4.667$, de 2004, é prever a obrigação originária do ente federado responsável pela violação de direitos humanos reconhecida na decisão internacional. A União ficaria, assim, apenas com a responsabilidade subsidiária na execução do pagamento da obrigação pecuniária determinada pela decisão dos Organismos Internacionais de Proteção aos Direitos Humanos, cuja competência for reconhecida pelo Estado brasileiro. Esse dispositivo facilitaria a compreensão das demais pessoas jurídicas de direito público acerca das suas responsabilidades por atos reconhecidos internacionalmente como ilícitos e poderia servir à maior efetividade das decisões, pelo menos nos pontos resolutivos relativos às indenizações.

De fato, uma norma de regulamentação do cumprimento de decisões internacionais permitiria aumentar a capacidade do sistema interno de ser permeável às questões discutidas e decididas nas instâncias internacionais, ao tempo em que possibilitaria a busca por algum grau de compatibilização das racionalidades de cada sistema. A comunicação entre eles pode ser mais fácil se as regras e a linguagem estiverem mais bem definidas para as pessoas que lidam com esse ponto de contato dos sistemas. Utilizando uma das hipóteses mencionadas, a do federalismo e sua lógica no sistema brasileiro, seria ponto importante de uma norma que tratasse do cumprimento das decisões da Corte Interamericana o estabelecimento da distribuição interna da responsabilidade dos atos pelos quais o país foi condenado, 
inclusive com regras sobre a responsabilidade dos agentes públicos. Os argumentos federativos tenderiam a ficar enfraquecidos diante de regras desse tipo.

As relações estabelecidas entre o Sistema Interamericano de Proteção de Direitos Humanos e o sistema jurídico brasileiro deveriam ser de interação, de fluxo contínuo de comunicação entre eles, com uma linguagem já estabelecida e de forma automática, sem a necessidade de procedimentos adicionais para estabelecer as conexões entre eles. Ocorre que a eficácia de uma decisão prolatada pela Corte Interamericana de Direitos Humanos não ocorre tão automaticamente quanto poderia parecer. Podem surgir dúvidas quanto à responsabilidade interna dos órgãos, entidades e agentes públicos, quanto ao procedimento a ser observado, quanto à competência para promover a execução e muitas delas já poderiam ser antecipadamente respondidas por uma norma do tipo enabling legislation.

Um exemplo disso refere-se à compreensão do requisito de esgotamento dos recursos internos para a admissibilidade de uma denúncia perante o Sistema Interamericano de Direitos Humanos, previsto no artigo 46, 1, “a” do Pacto de San José da Costa Rica, em atenção ao caráter complementar do Sistema em relação às instituições nacionais. Segundo esse requisito, é necessário que tenham sido interpostos e esgotados os recursos da jurisdição interna, de acordo com os princípios de direito internacional geralmente reconhecidos. Há algumas exceções, previstas no mesmo instrumento: não existir meios adequados, na legislação interna do Estado para a proteção do direito violado, não se houver permitido à vítima o acesso aos recursos da jurisdição interna, ou houver sido ela impedida de esgotá-los e ter havido demora injustificada na decisão sobre os mencionados recursos, este último bastante significativo para a experiência brasileira.

Algumas autoridades públicas, dentro da racionalidade do sistema jurídico brasileiro, não compreendem como pode um determinado fato, ainda em discussão judicial no Brasil, já estar sob o exame de uma instância internacional e, surpreendentemente, já ter sido por ela julgado, recusando-se a dar cumprimento, no âmbito de suas atribuições funcionais, à decisão internacional. Os órgãos integrantes do Sistema Interamericano entendem que o acesso à justiça deve ser feito por meios efetivos e em um prazo razoável, sob pena de, por si só, esse fato configurar 
violação aos direitos previstos nos artigos $8^{\circ}$ e 25 da Convenção Americana. ${ }^{48}$ Os órgãos internos podem eventualmente entender que devem manter a contestação judicial do caso, amparada no princípio da indisponibilidade do interesse público. Cumprir a decisão internacional seria, nessa linha, transigir com o interesse público em uma hipótese em que não há, em regra, autorização legal para tanto. A previsão legal para agir de modo a cumprir a decisão internacional serviria como forma de compatibilização de noções, de lógicas e de racionalidades entre os sistemas.

Diante da ausência de disciplina sobre o tema da execução de decisões internacionais, no tocante àquelas advindas da Corte Interamericana de Direitos Humanos, o artigo 68.2 da Convenção Americana sobre Direitos Humanos determina que, quanto à indenização pecuniária, deve ser observado o procedimento adotado para a execução de sentenças contra o Estado, que consiste no procedimento dos precatórios judiciais. Previsto nos artigos 100 da Constituição Federal e 730 e 731 do Código de Processo Civil, o procedimento de precatórios determina que seja expedida ordem de pagamento, que deve ser incluída em uma lista de espera pelo seu adimplemento. Esses pagamentos são realizados de acordo com a disponibilidade de recursos orçamentários do ente federado, podendo esperar até que haja recursos suficientes. A experiência demonstra que, em alguns casos, esse procedimento pode demorar muito tempo, até anos, o que seria de difícil aceitação por parte da Corte Interamericana, podendo até a demora no pagamento configurar nova violação da Convenção Americana. ${ }^{49}$

A edição de normas que disciplinem o cumprimento das decisões internacionais, mais especificamente daquelas proferidas pelos órgãos integrantes do Sistema Interamericano de Proteção aos Direitos Humanos, se não necessária, seria extremamente útil e facilitadora do procedimento de execução dessas decisões, efetivando a proteção dos indivíduos, aclarando atribuições, determinando res-

${ }^{48}$ CORTE INTERAMERICANA DE DIREITOS HUMANOS. Ximenes Lopes contra Brasil (Sentença de 4 de julho de 2006, par. 171-206).

49 TRINDADE, Otávio Augusto Drummond Cançado. Os efeitos das decisões dos tribunais internacionais de direitos humanos no direito interno dos Estados. In: LEÃO, Renato Zerbini Ribeiro. (Coord.). Os rumos do direito internacional dos direitos humanos: ensaios em homenagem ao Professor Antônio Augusto Cansado Trindade. Porto Alegre: S. A. Fabris, 2005. p. 311. 
ponsabilidades e aproximando as instâncias internacional e interna. Nesse panorama, ainda que desnecessário diante da disciplina atual, o advento de uma enabling legislation parece capaz de minimizar esses problemas do ponto de vista jurídico, uma vez que criaria mecanismos institucionais permanentes e esclareceria as atribuições de cada um nesse processo.

\section{Considerações finais}

As questões que estão atualmente em debate em razão da Arguição de Descumprimento de Preceito Fundamental n ${ }^{\circ} 153$ no Supremo Tribunal Federal e do Caso "Julia Gomes Lund e Outros" (Guerrilha do Araguaia) na Corte Interamericana de Direitos Humanos relativas à validade da Lei de Anistia brasileira colocam o Estado democrático brasileiro, suas instituições e seus compromissos internacionais em foco ao mesmo tempo. Em primeiro lugar, o Estado democrático pode ser afetado pelos desdobramentos dessas questões, pois afirma valores contrários aos regimes de exceção desde a Constituição de 1988. Segundo, as instituições brasileiras podem sofrer as consequências das decisões desses dois casos, porque algumas delas travaram certa disputa pelo prestígio dos seus entendimentos e as mais altas delas, inclusive o Supremo Tribunal Federal, podem restar enfraquecidos nessa disputa. Por fim, o país pode se ver compelido ao inadimplemento de compromissos internacionalmente assumidos, o que pode ter como consequência a sua retirada de importantes foros mundiais.

A decisão prolatada no Caso Guerrilha do Araguaia pela Corte Interamericana de Direitos Humanos declarou expressamente a impossibilidade de invocar disposições de anistia, de prescrição ou excludentes de ilicitude para obstaculizar o cumprimento da obrigação de investigar os fatos e punir os responsáveis por graves violações de direitos humanos, como: torturas, execuções sumárias e desaparecimentos forçados. Assim, a aplicação dada pelo Poder Judiciário brasileiro à Lei de Anistia, inclusive na decisão do Supremo Tribunal Federal na ADPF n ${ }^{\circ}$ 153, segundo a decisão, não observou o necessário controle de convencionalidade dessa norma em face dos compromissos assumidos pelo país no plano internacional. 
Como consequência desse entendimento, a Corte Interamericana de Direitos Humanos determinou a investigação penal dos fatos, a apuração das responsabilidades e a aplicação das sanções correspondentes, afrontando o que ficou decidido por sete votos a dois na $\mathrm{ADPF} \mathrm{n}^{\circ}$ 153. A decisão internacional não determinou a invalidação da decisão do Supremo Tribunal Federal ou a revogação da Lei de Anistia, o que atualmente coloca a situação de coexistência das duas decisões, uma interna e outra internacional, com conteúdos bem distintos, senão opostos.

Não pretende este trabalho apontar prognósticos sobre a situação posta de forma inédita na experiência brasileira. O Supremo Tribunal Federal não havia ainda decidido sobre a Lei de Anistia nos termos em que foi colocada a questão na ADPF em tela. A Corte Interamericana, por sua vez, já havia se manifestado em situações análogas, sobre regimes ditatoriais ocorridos na América Latina, e firmou entendimento no sentido do reconhecimento de responsabilidade internacional ao Estado pela edição de lei de anistia e de que a lei de anistia é incompatível com a Convenção Americana sobre Direitos Humanos. ${ }^{50}$

Em razão do que foi exposto, parece mais adequado compreender que o Sistema Interamericano de Proteção de Direitos Humanos e o sistema jurídico brasileiro são dois sistemas distintos e autônomos, uma vez que possuem regras e racionalidades diferentes, possuem limites próprios e se diferenciam do seu entorno e entre si. A partir disso, é possível apontar alguns meios que facilitem a interação entre eles, de forma a dirimir dificuldades no adimplemento dos compromissos e das decisões internacionais relativas ao Brasil, de forma a avançar no campo da proteção dos direitos humanos. As relações travadas pelos dois sistemas devem, para o aprimoramento da experiência brasileira, ser de interação e não de antinomia. Não interessa ao Estado brasileiro contrariar seus próprios fundamentos, objetivos e princípios determinados pelos artigos $1^{\circ}, 3^{\circ}$ e $4^{\circ}$ da Constituição Federal.

${ }^{50}$ CORTE INTERAMERICANA DE DIREITOS HUMANOS. Barrios Altos contra Peru (Sentença de 14 de março de 2001).

CORTE INTERAMERICANA DE DIREITOS HUMANOS. La Cantuta contra Peru (Sentença de 29 de novembro de 2006).

CORTE INTERAMERICANA DE DIREITOS HUMANOS. Almonacid Arellano e Outros contra Chile (Sentença de 26 de setembro de 2006). 
Diante da afirmação de que o Sistema Interamericano de Proteção de Direitos Humanos e o sistema jurídico brasileiro são dois sistemas distintos e autônomos, é necessário analisar os efeitos de eventuais conflitos materiais entre eles em dois planos: o jurídico e o político. No primeiro plano, conforme o entendimento do Supremo Tribunal Federal sobre a estatura interna dos tratados a respeito dos direitos humanos, é possível vislumbrar três situações. Na primeira delas, que diz respeito à divergências entre os conteúdos das decisões da Corte Interamericana e das decisões do Supremo Tribunal quanto à interpretação que a Constituição brasileira dá a normas internas, deve prevalecer o entendimento da Corte Interamericana de Direitos Humanos, em razão do caráter supralegal da Convenção Americana sobre Direitos Humanos. Caso os conflitos versem sobre norma interna brasileira, pelo mesmo motivo, deve prevalecer o disposto na decisão do tribunal internacional mencionado. Por fim, em uma terceira hipótese, se ocorrer conflito material entre decisões que versem sobre a interpretação da Constituição brasileira à luz das regras que integram o Sistema Interamericano de Proteção aos Direitos Humanos, pelo que foi exposto neste trabalho, parece-nos que prevalecerá o entendimento do Supremo Tribunal Federal. Os órgãos internos, fundados na supremacia da Constituição, afastariam os efeitos da decisão da Corte Interamericana.

No plano político externo, caso fossem negados efeitos à decisão da Corte Interamericana de Direitos Humanos, ocorreria o descumprimento das obrigações internacionalmente assumidas perante o Sistema Interamericano e a OEA, podendo o país sofrer as sanções previstas na Carta da OEA, dentre elas, a exclusão, e adquirir a reputação internacional de um país que não cumpre os seus acordos e viola direitos humanos, indesejada para os países no cenário mundial. Internamente, ainda quanto a efeitos políticos, a sociedade brasileira sentiria os reflexos do rompimento com o Sistema Interamericano e com a OEA, uma vez que já há muitas experiências exitosas advindas da participação do Brasil. É fundamental que o Brasil integre o Sistema Interamericano e promova as mudanças oriundas das decisões e acordos internacionais.

O desafio que se impõe é o de promover a interação entre os dois sistemas, ao invés de possibilitar a antinomia ou a rivalidade entre eles. Uma proposição que colabora com a interação entre os dois sistemas é a edição de normas que regula- 
mentam o cumprimento das decisões da Corte Interamericana de Direitos Humanos, possibilitando a harmonização das diferenças entre os dois sistemas e, assim, a melhor comunicação entre eles. Os conflitos que porventura surjam seriam mais bem resolvidos pela compatibilização das lógicas ou racionalidades envolvidas, buscando uma "linguagem" comum a eles, que pelas soluções tradicionais de regras de hierarquia entre normas e órgãos. ${ }^{51}$

À vista das dificuldades que podem se instalar diante da execução da decisão do Caso Guerrilha do Araguaia no plano interno, deixar o cumprimento das decisões da Corte Interamericana de Direitos Humanos sem qualquer disciplina interna pode aumentar a distância entre os dois sistemas ora examinados. Diante desses fatos, seria importante enfrentar as dificuldades que podem se apresentar na solução da questão e buscar maior interação com os órgãos do Sistema Interamericano. Foram sugeridas algumas possibilidades ao longo deste trabalho, porém certamente não as únicas. Os direitos humanos estão atualmente ${ }^{52}$ a serviço de uma política progressista e emancipatória, se são entendidos em uma concepção multicultural. É importante oferecer ao Sistema Interamericano as particularidades do sistema jurídico brasileiro e receber do Sistema as lições da sua experiência. Do diálogo e da interação fundados na compatibilização, e não na homogeneização das diferenças, certamente resultarão ganhos para ambos.

\section{The implementation of Inter-American CourtofHumanRights deci- sions andthe Brazilian legal systemdecisions and itseffects}

\section{Abstract}

In the case of conflict between the material content of an Inter-American Court of Human Rights decision and a Supreme Court decision that deal with the

${ }^{51}$ FISCHER-LESCANO, Andreas; TEUBNER, Gunther. Regime-collisions: the vain search for legal unity in the fragmentation of global law. Michigan Journal of International Law, Ann Arbor, v. 25, n. 4, p. 1045-1046, 2004.

52 SANTOS, Boaventura de Sousa; NUNES, João Arriscado. Introdução: para ampliar o cânone do reconhecimento, da diferença e da igualdade. In: SANTOS, Boaventura de Sousa (Org.). Reconhecer para libertar. Rio de Janeiro: Civilização Brasileira, 2003. p. 25-67. 
same object, which one will take effect in the Brazilian Law? The Amnesty Law (n. 6683/1979) was examined by an international court and by the Supreme Court and they disagreed about the law interpretation, particularly regarding the punishment of state agentes that committed human rights violations. Which of these decisions will take effect domestically instead of the other? I intend to check the relations between international and internal bodies, to propose ways to answer some questions and to see if the Brazilian legal system is able to face a challenging international decision and what is the possible or likely solution. Thus, the hypothesis of this study focuses on the need to rule the relations between the two instances and some tools of the systems theory and other countries laws about the same issue were used to test it. After all, how could be described the relationship between the Inter-American System of Protection of Human Rights and the Brazilian legal system? Integration, interaction or contradiction?

Keywords: International Law. Inter-American Courtof Human Rights. Humanrights. International justice.

\section{Referências}

BRASIL. Decreto $n^{\circ}$ 678, de 1992. Disponível em: <www.presidencia.gov.br>. Acesso em: 14 jan. 2010.

BRASIL. Decreto $n^{\circ}$ 89, de 1998. Disponível em: <www.senado.gov.br>. Acesso em: 1 fev. 2010.

BRASIL. Decreto $n^{\circ}$ 6.949, de 25 de agosto de 2009. Disponível em: <www. presidencia.gov.br>. Acesso em: 31 jan. 2010.

BRASIL. Supremo Tribunal Federal. Recurso Extraordinário $n^{\circ} 466343$. (voto em 3 de dezembro de 2008).

BRASIL. Arguição de Descumprimento de Preceito Fundamental nº 153. Disponível em: <www.stf.jus.br>. Acesso em: 22 jan. 2010.

CASSESE, Antonio. International Law. New York: Oxford University, 2001. 
CORTE INTERAMERICANA DE DIREITOS HUMANOS. Almonacid Arellano e Outros contra Chile (Sentença de 26 de setembro de 2006).

CORTE INTERAMERICANA DE DIREITOS HUMANOS. Bámaca Velásquez contra Guatemala (Sentença de 25 de novembro de 2000).

CORTE INTERAMERICANA DE DIREITOS HUMANOS. Barrios Altos contra Peru (Sentença de 14 de março de 2001).

CORTE INTERAMERICANA DE DIREITOS HUMANOS. Comunidade Indígena Yakye Axa contra Paraguai (Sentença de 17 de junho de 2005).

CORTE INTERAMERICANA DE DIREITOS HUMANOS. Comunidade Indígena Sawhoyamaxa contra Paraguai (Sentença de 29 de março de 2006).

CORTE INTERAMERICANA DE DIREITOS HUMANOS. Comunidade Mayagna (Sumo) Awas Tingni contra a Nicarágua (Sentença de 31 de agosto de 2001).

CORTE INTERAMERICANA DE DIREITOS HUMANOS. Damião Ximenes Lopes contra Brasil (Sentença de 4 de julho de 2006).

CORTE INTERAMERICANA DE DIREITOS HUMANOS. Damião Ximenes Lopes contra Brasil (Resolução de 17 de maio de 2010).

CORTE INTERAMERICANA DE DIREITOS HUMANOS. Escher e Outros contra Brasil (Sentença de 6 de julho de 2009).

CORTE INTERAMERICANA DE DIREITOS HUMANOS. Garrido e Baigorria contra Argentina (Sentença de 27 de agosto de 1998).

CORTE INTERAMERICANA DE DIREITOS HUMANOS. La Cantuta contra Peru (Sentença de 29 de novembro de 2006).

CORTE INTERAMERICANA DE DIREITOS HUMANOS. Masacre Plan de Sanchez contra Guatemala (Sentença de 29 de abril de 2004).

CORTE INTERAMERICANA DE DIREITOS HUMANOS. Medidas Provisórias decretadas para a Penitenciária “Dr. Sebastião Martins Silveira” em Araraquara (Resolução de 25 de novembro de 2008). 
CORTE INTERAMERICANA DE DIREITOS HUMANOS. Medidas Provisórias decretadas para o "Complexo do Tatuapé" da FEBEM (Resolução de 25 de novembro de 2008).

CORTE INTERAMERICANA DE DIREITOS HUMANOS. Medidas Provisórias decretadas para o Presídio Urso Branco (Resolução de 2 de maio de 2008).

CORTE INTERAMERICANA DE DIREITOS HUMANOS. Opinião Consultiva OC-16/99, $1^{\circ}$ de outubro de 1999.

CORTE INTERAMERICANA DE DIREITOS HUMANOS. Villagrán Morales y otros contra Guatemala ("Niños de la Calle") (Sentença de 19 de novembro de 1999).

FISCHER-LESCANO, Andreas; TEUBNER, Gunther. Regime-collisions: the vain search for legal unity in the fragmentation of global law. Michigan Journal of International Law, Ann Arbor, v. 25, n. 4, 2004.

FRAGA, Mirtô. O conflito entre tratado internacional e norma de direito interno. Rio de Janeiro: Forense, 1998.

KRSTICEVIC, Viviana. Reflexões sobre a execução das decisões do Sistema Interamericano de Proteção dos Direitos Humanos. In: CENTRO PELA JUSTIÇA E O DIREITO INTERNACIONAL (Org.) Implementação das decisões do Sistema Interamericano de Direitos Humanos: jurisprudência, instrumentos normativos e experiências nacionais. Rio de Janeiro: CEJIL, 2009.

LUHMANN, Niklas. Risk: a sociological theory. Traduzido por Rhodes Barret. New York: Aldine de Gruyter, 1993.

MAZZUOLI, Valério de Oliveira. Curso de direito internacional público. 2. ed. rev. atual. e ampl. São Paulo: Revista dos Tribunais, 2007.

PEREIRA, Luis Cezar Ramos. Ensaio sobre a responsabilidade internacional do Estado e suas consequências no Direito Internacional. São Paulo: LTr, 2000.

PIOVESAN, Flávia. Direitos humanos e o direito constitucional internacional. São Paulo: Saraiva, 2007.

PIOVESAN, Flávia. Implementation through intrastate levels of government, including federal, state/provincial and municipal jurisdictions. In: Working session on the implementation of international human rights obligations and standards 
in the Inter-American System, 2003, Washington. Anais eletrônicos... Washington: Comissão Interamericana de Direitos Humanos, 2003. Disponível em: <www. internationaljusticeproject.org/pdfs/Piovesan-speech.pdf>. Acesso em: 31 jan. 2010.

REZEK, Francisco. Direito internacional púbico: curso elementar. 11. ed. rev. e atual. São Paulo: Saraiva, 2008.

SANTOS, Boaventura de Sousa; NUNES, João Arriscado. Introdução: para ampliar o cânone do reconhecimento, da diferença e da igualdade. In: SANTOS, Boaventura de Sousa (Org.). Reconhecer para libertar. Rio de Janeiro: Civilização Brasileira, 2003.

SERRANO, José Luís. La diferencia riesgo/peligro. In: VARELLA, Marcelo Dias (Org.). Direito, sociedade e riscos. Brasília: UniCEUB; UNITAR, 2006.

TRINDADE, Otávio Augusto Drummond Cançado. Os efeitos das decisões dos tribunais internacionais de direitos humanos no direito interno dos Estados. In: LEÃO, Renato Zerbini Ribeiro. (Coord.). Os rumos do direito internacional dos direitos humanos: ensaios em homenagem ao Professor Antônio Augusto Cansado Trindade. Porto Alegre: S. A. Fabris, 2005.

VARELLA, Marcelo D. Direito internacional público. São Paulo: Saraiva, 2009. 


\section{Para publicar na revista Prismas: Direito, Políticas}

Públicas e Mundialização, acesse o endereço eletrônico www.publicacoesacademicas.uniceub.br. Observe as normas de publicação, para facilitar e agilizar o trabalho de edição. 